

\section{DISCLAIMER}

This report was prepared as an account of work sponsored by an agency of the United States Government. Neither the United States Government nor any agency Thereof, nor any of their employees, makes any warranty, express or implied, or assumes any legal liability or responsibility for the accuracy, completeness, or usefulness of any information, apparatus, product, or process disclosed, or represents that its use would not infringe privately owned rights. Reference herein to any specific commercial product, process, or service by trade name, trademark, manufacturer, or otherwise does not necessarily constitute or imply its endorsement, recommendation, or favoring by the United States Government or any agency thereof. The views and opinions of authors expressed herein do not necessarily state or reflect those of the United States Government or any agency thereof. 


\section{DISCLAIMER}

Portions of this document may be illegible in electronic image products. Images are produced from the best available original document. 
TID-4500, UC-51

Geology and Mineralogy

\section{㢟 \\ LAWRENCE LUNERMORE LABORATORY \\ University of Caffornia/ Livermore, Callitomia 94550}

UCRL-51366

\section{THE TOTAL FLOW CONCEPT FOR RECOVERY OF ENERGY FROM GEOTHERMAL HOT BRINE DEPOSITS}
A. L. Austin
G. H. Higgins
J. H. Howard

MS. date: April 3, 1973

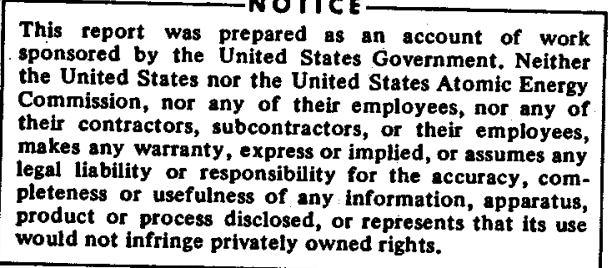


$\mathcal{L}$

4 .

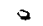




\section{Contents}

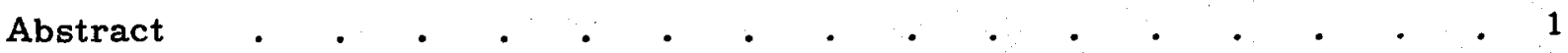

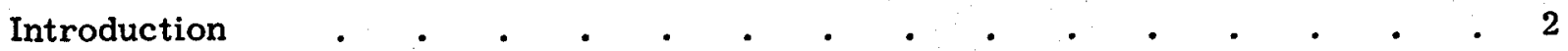

Extent and Characteristics of the Hot Brine Resource _ . . . . . . . 4

Volume and Areal Distribution of Hot Brine in the Salton Trough $\quad$. . . 4

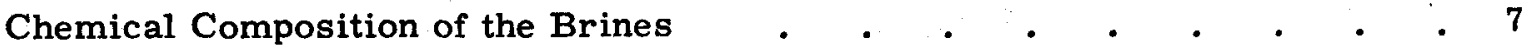

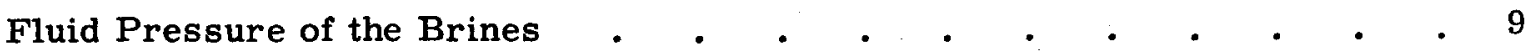

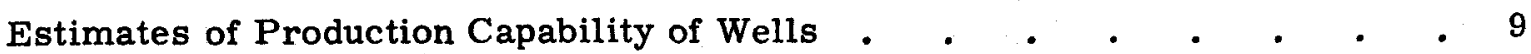

Mechanism for Generating Geothermal Heat in the Salton Trough _ . . 12

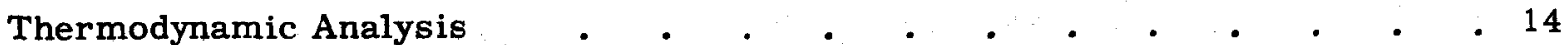

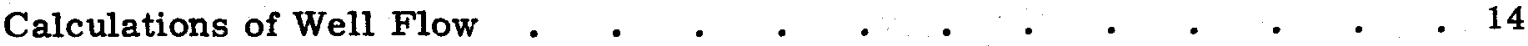

The Total Flow System $\quad$ •

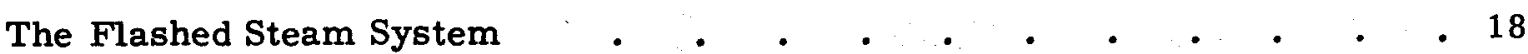

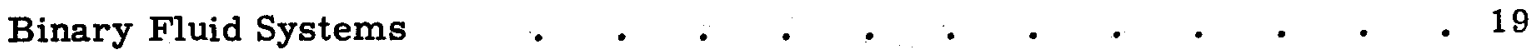

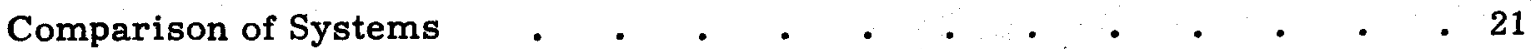

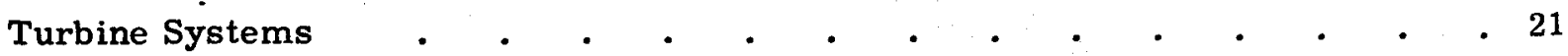

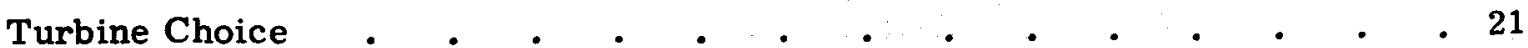

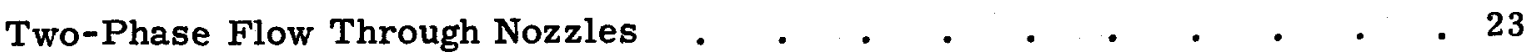

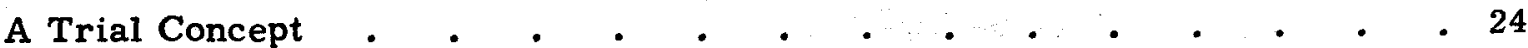

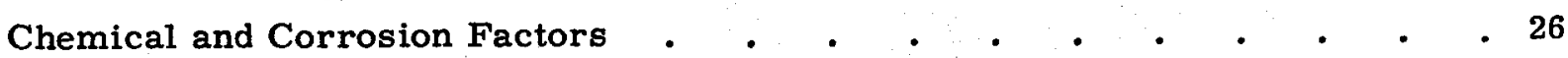

Brine Physical and Thermal Properties . . . . . . . . . . . 26

Corrosion . . . . . . . . . . . . . . . . . 26

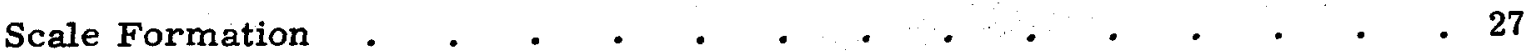

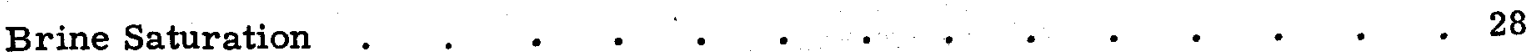

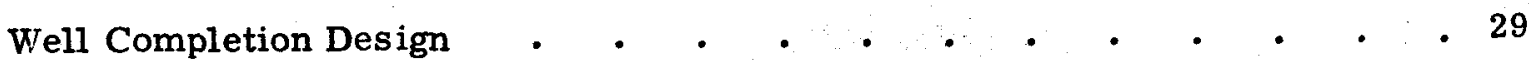

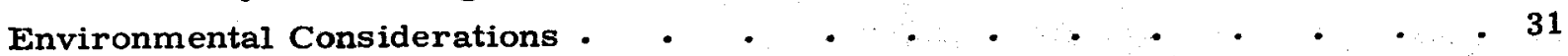

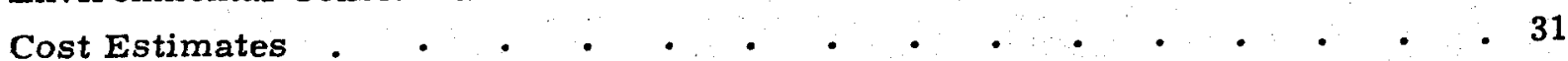

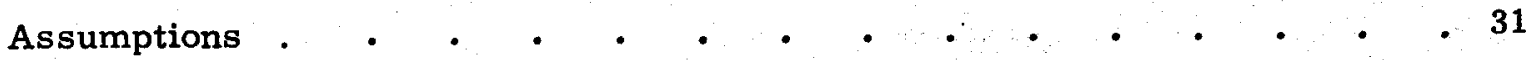

Capital Costs . $\quad$ • . . . . . . . . . . 32

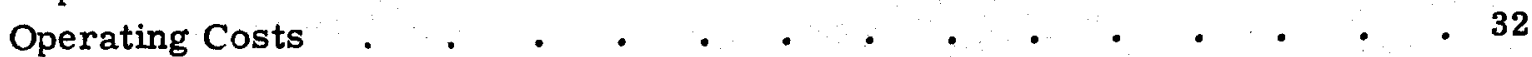

Cash Flow and Profitability

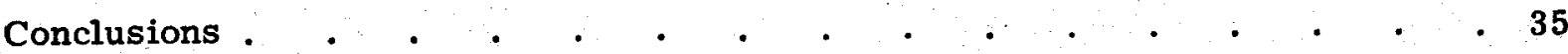

References . . . . . . . . . . . . . . . . . . 36 


\title{
THE TOTAL FLOW CONCEPT FOR RECOVERY OF ENERGY FROM GEOTHERMAL HOT BRINE DEPOSITS
}

\begin{abstract}
This report describes a new method for producing electrical power from the energy stored in hot brine deposits. Of the three forms of geothermal energy, the hot brine resource has the greatest potential for development of a viable longrange geothermal energy supply. It is a large energy source with recovery and conversion requiring only moderate extensions of existing technologies.

The proposed method is developed specifically for application to the brines of the Salton Sea geothermal area, where enough energy is stored to provide at least $100,000 \mathrm{MW}$ electrical generation capacity for more than $20 \mathrm{yr}$. These brines contain up to $30 \%$ dissolved salts and are very corrosive. Once developed, the proposed method, then, will certainly be applicable to other geothermal deposits.

The method uses the total flow concept. Hot brine is allowed to expand (from $300^{\circ} \mathrm{C}, 2200$ psia, at $\sim 5000 \mathrm{ft}$ ) to the surface where the wellhead product contains $\sim 20 \%$ vapor by weight and $=\quad \sim 560 \mathrm{Btu} / \mathrm{lb}$ at 400 psia. This thermal

energy is converted to kinetic energy by expansion of the mixture through a converging-diverging nozzle. The high velocity output is used to drive a modified hydraulic impulse turbine operating at $\sim 3.5 \mathrm{in}$. $\mathrm{Hg}\left(120^{\circ} \mathrm{F}\right)$. Theoretically, this method should produce $60 \%$ more power than other systems, either operational or proposed, for the hot brine application. The basic advantage is that the total flow is used, allowing recovery of energy in the liquid that otherwise would be lost. The use of hydraulic impulse turbine concepts is attractive since much of the needed technology exists, the devices are inherently rugged, and fabrication with corrosion-erosion resistant materials is possible.

We estimate that an electrical power generation station using this concept will require a capital investment of $\sim \$ 200 / \mathrm{kW}$ and should produce power at a cost of $\sim 3 \mathrm{mills} / \mathrm{kWh}$. For a power sales price of 8 mills $/ \mathrm{kWh}$, we estimate the internal rate of return to be between $10 \%$ and $20 \%$, depending on the method of taxation and royalty charges.
\end{abstract}




\section{Introduction}

The total geothermal energy resource base in the United States is very large. White, ${ }^{1}$ for example, estimates that the geothermal energy stored under the United States to a depth of $6 \mathrm{mi}$ is on the order of $10^{22} \mathrm{Btu}$; this estimate is generally regarded as conservative by others concerned with evaluating the magnitude of the geothermal resource base. ${ }^{2}$ Geothermal energy exists in near-surface deposits as superheated steam, hot brine, and hot dry rock. We propose a method for production of electrical power from the energy in hot brine, especially the brines of the Salton Sea geothermal area in California. This energy form appears to represent the largest potentially exploitable part of the geothermal energy resource base. Although superheated steam deposits, such as those at The Geysers, California, are more desirable forms of geothermal energy than are hot brine deposits, they are estimated to be only one-twentieth as common. ${ }^{3}$. On the other hand, although there is an immense amount of energy in dry hot rock, power output is limited by the inherent low thermal conductivity of rock, and no technology yet exists for its recovery and conversion.

The proposed method for producing power from hot brine uses the "total fluid flow" concept. We consider it to be economically competitive with all other electric power sources. Conceivably it can develop power from hot brine deposits in California equivalent to $100,000 \mathrm{MW}$ of electrical generating capacity. By comparison, the present electrical generating capacity of the United States is $\sim 340,000 \mathrm{MW}$.

Other approaches have been proposed for using hot brine. One consists of flashing the brine in a centrifugal separator, disposing of the liquid fraction, and

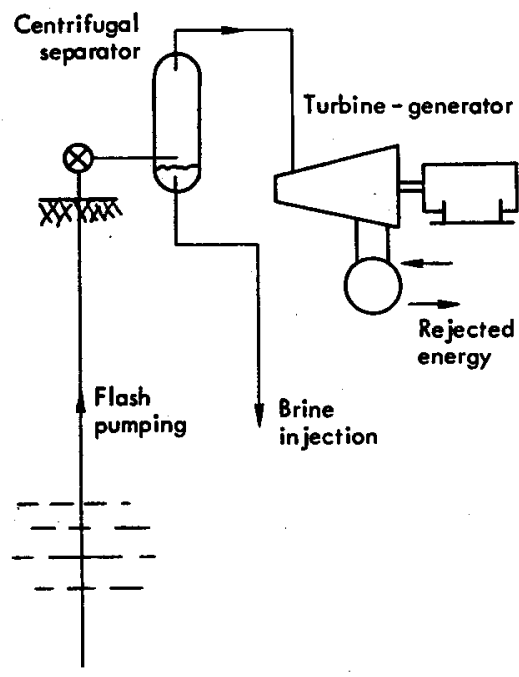

A. Flashed steam system

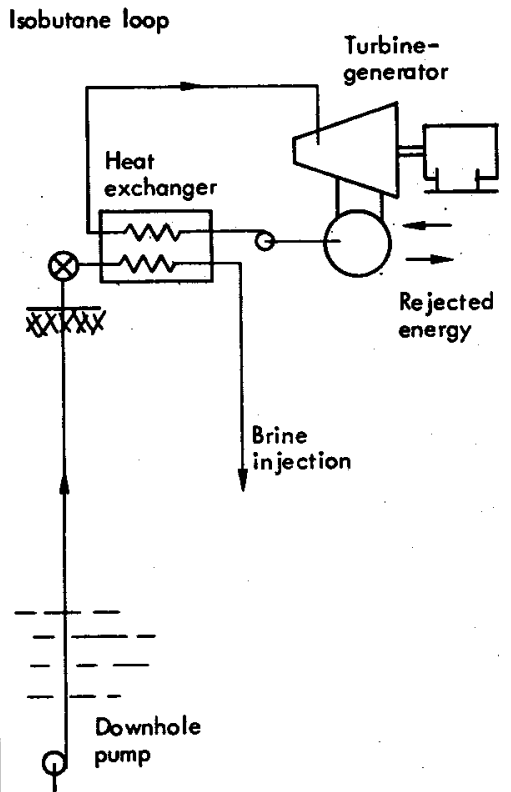

B. Binary fluid system

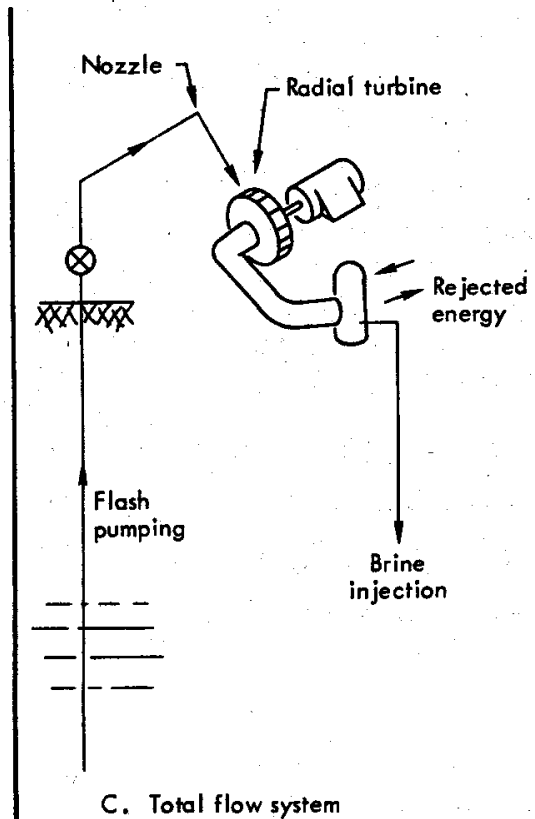

Fig. 1. Methods for recovery of energy from hot brine deposits. 
operating a conventional reaction turbine with the retained vapor fraction. This system is used at Wairakei, New Zealand, and is the system under construction at Cerro Prieto, Mexico. The brines at these locations have salt contents about one-tenth that of the Salton Sea brines, and it is clear that high salt content has inhibited similar developments of the Salton Sea deposit. We hope to find feasible and economically acceptable solutions to the problems associated with this brine; e.g., corrosion and scaling.

A second approach to using hot brine is a binary fluid system in which hot brine is pumped under pressure to prevent flashing and passed through a heat exchanger to transfer the thermal energy to a noncorrosive working fluid such as isobutane. This fluid is then used in a Rankine cycle turbine-alternator system for producing electrical energy. In view of the corrosive nature of the brine, we believe that reliable operation of the downhole pump and the heat exchanger required in the concept is a difficult problem that currently limits application of the concept.

We have conceived a third approach ${ }^{*}$ that in theory requires a capital investment of $\sim \$ 200 / \mathrm{kW}$ and should produce

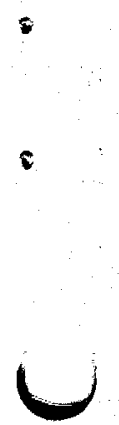

* A fourth system in which the total flow is processed through an MHD generator was also examined and appears technically feasible. The electrical resistivity of the brine-steam mixture should be about $147 \mathrm{\Omega}-\mathrm{cm}$ at the entrance to the magnet and about 10 times higher at the exit. 4 However, the magnet for a 100-MW maand the conversion efficiency should not chine would be on the order of $100 \mathrm{ft}^{10 n g}{ }^{5}$ energy at a cost of $3.2 \mathrm{mills} / \mathrm{kWh}$. These estimates are lower than those for both the flashed steam and binary fluid systems. The proposed method consists of allowing the brine to expand to the surface as is now being done at Wairakei and at Cerro Prieto, and then expanding the total fluid stream through a nozzle to low pressure and high velocity. The kinetic energy of the entire fluid stream would then be used in a corrosion-resistant impulse turbine, modeled after typical hydroelectric devices, to drive an electrical generating system. Theoretically, this method should produce $\sim 1.6$ times as much power from a given well as either the flashed steam system or the binary fluid system. Since fewer mechanical components are required at the surface, capital costs should be less, despite the need to protect against corrosive brines.

Figure 1 contrasts the three methods. Note that in the flashed steam system (Fig. 1a) and the binary fluid system (Fig. 1b) brine is discarded at temperatures higher than the turbine outlet and ambient temperatures for waste heat disposal. Thus, insofar as turbine efficiencies for all systems are comparable, the total flow system (Fig. 1c) must always have a higher overall efficiency.

differ greatly from that of a turbine. The only advantage to the MHD system seems to be the absence of moving parts in the machine to corrode or erode. Since other system components in the well and condenser system would still have corrosion costs, we concluded that the capital costs for the MHD system offset its advantages and attempted no further detailed analyses. 


\section{Extent and Characteristics of the Hot Brine Resource}

Figure 2 shows the areal distribution of existing and potential geothermal fields in the western United States. 6 Included in these areas are dry steam and hot rock geothermal resources as well as hot brine resources. The only facility presently recovering geothermal heat is at The Geysers, where dry steam is used to produce more than $100 \mathrm{MW}$ of electricity.

The area on which we focus lies within the western geothermal province in southern California and northwestern Mexico. Topographically the area is the landward extension of the Gulf of California. It includes the Coachella, Imperial, and Mexicali Valleys and the Salton $\mathrm{Sea}^{7}$ (see Fig. 3). We refer to the entire low-lying area as the Salton Trough. Geothermal resources have been extensively explored

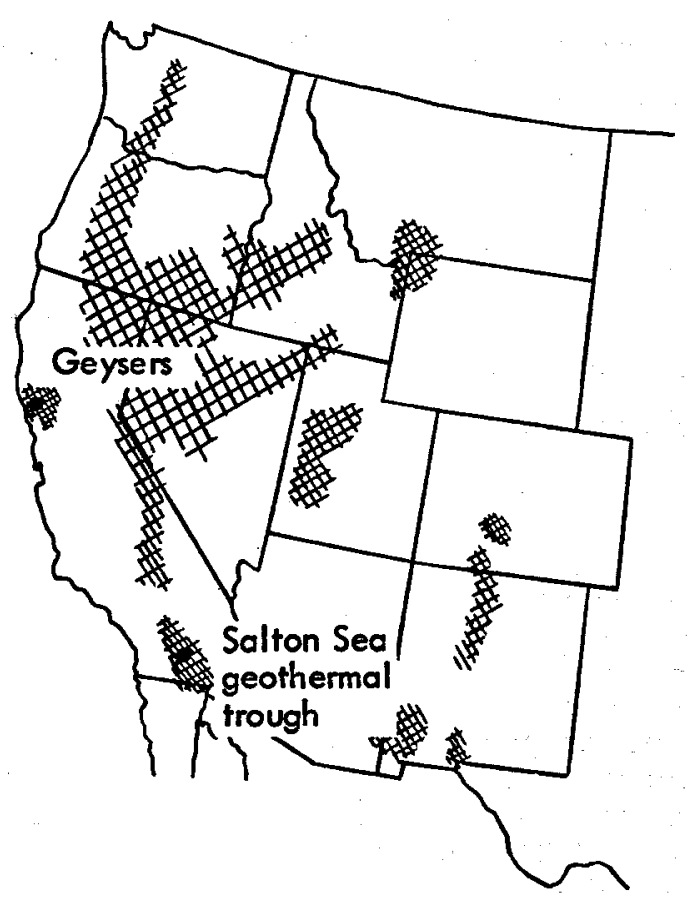

Fig. 2. Existing and potential geothermal areas of the western United States. in both the Imperial Valley (the Salton Sea geothermal area) and the Mexicali Valley (the Cerro Prieto geothermal area). Both these areas appear to be manifestations of the same geological system of heat flow in this part of the earth.

\section{VOLUME AND AREAL DISTRIBU- TION OF HOT BRINE IN THE SALTON TROUGH}

It is possible to define certain important characteristics of the geothermal resource even though its distribution in the Salton Trough is incompletely known. Direct observations show, for instance, that brines with temperatures $>300^{\circ} \mathrm{C}$ occur at the Salton Sea geothermal area and at Cerro Prieto. 8,9 Our knowledge of the distribution of brines with temperatures $>300^{\circ} \mathrm{C}$ elsewhere in the area is based on temperature data obtained in wells of various depths and from springs. ${ }^{10}$ Figure 4 is our interpretation of the surface of the $300^{\circ} \mathrm{C}$ isotherm, based on maps and cross-sections provided by the U.S. Geological Survey. ${ }^{10}$ According to Dutcher, the U.S.G.S. figures are "conservative" extrapolations of temperatures to be expected at depth. ${ }^{11}$ More liberal extrapolation of near-surface thermal gradients suggest that still higher temperatures could be expected at depth. 12

Figure 4 shows that the $300^{\circ} \mathrm{C}$ isotherm lies at depths of $<4000 \mathrm{ft}$ at the south end of the Salton Sea and at Cerro Prieto. Elsewhere it lies at greater depths. The surface has "highs" southeast of El Centro, east of Holtville, and near Brawley. These locations correspond to 
areas of high geothermal gradients reported by Elders et al. 12

Figure 5 shows the surface of the basement complex. In principle, this is an important surface because it probably represents the lowest depths at which hot brines might be recovered. We assume that the basement complex has essentially zero permeability and that fluids will not flow in it.

Comparing the top and bottom of the rock volume containing brines with temperatures $>300^{\circ} \mathrm{C}$ (Figs. 4 and 5) shows that the volume of $>300^{\circ} \mathrm{C}$ brine is

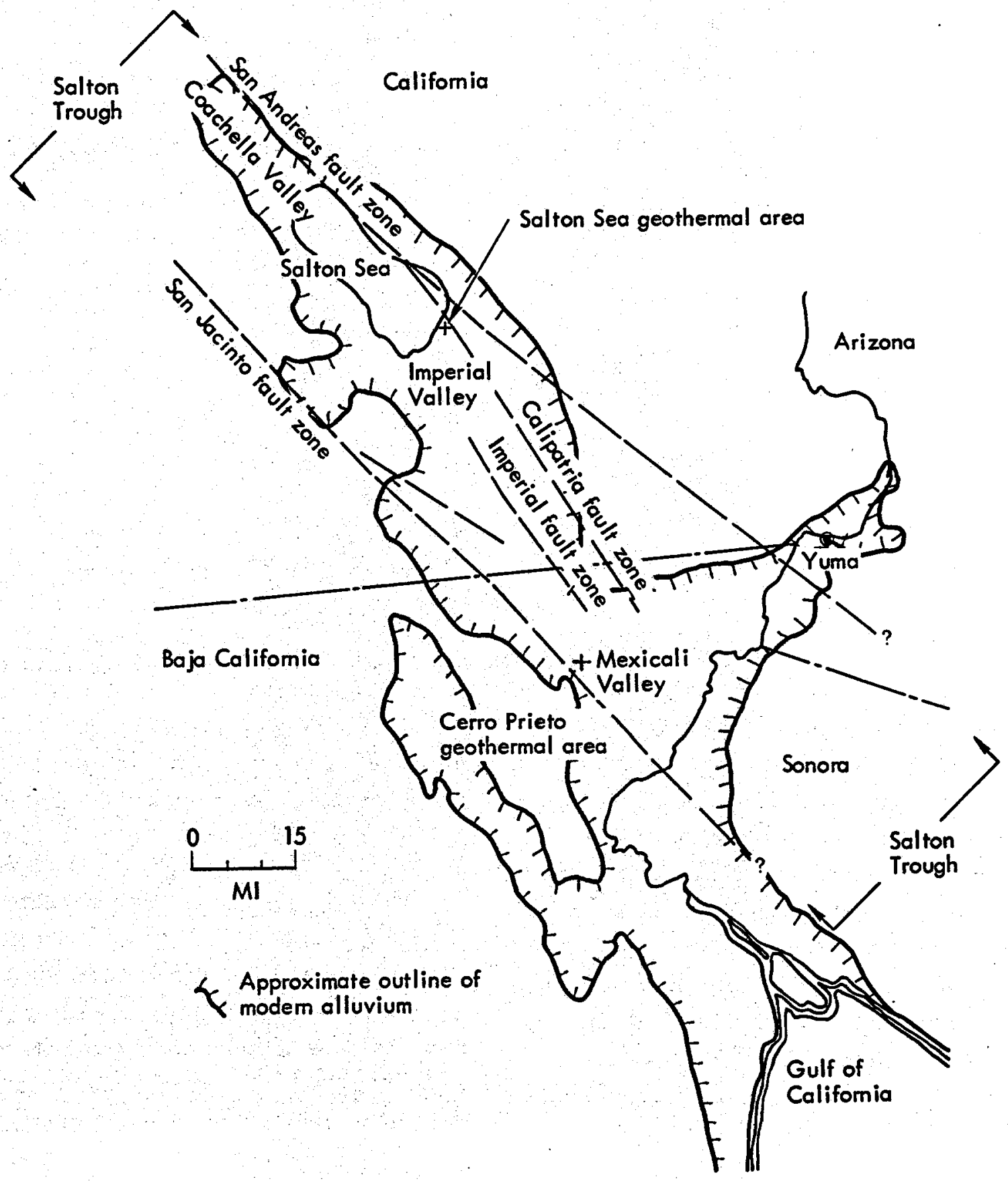

Fig. 3. Outline map of the Salton Trough. After Ref. 7. 


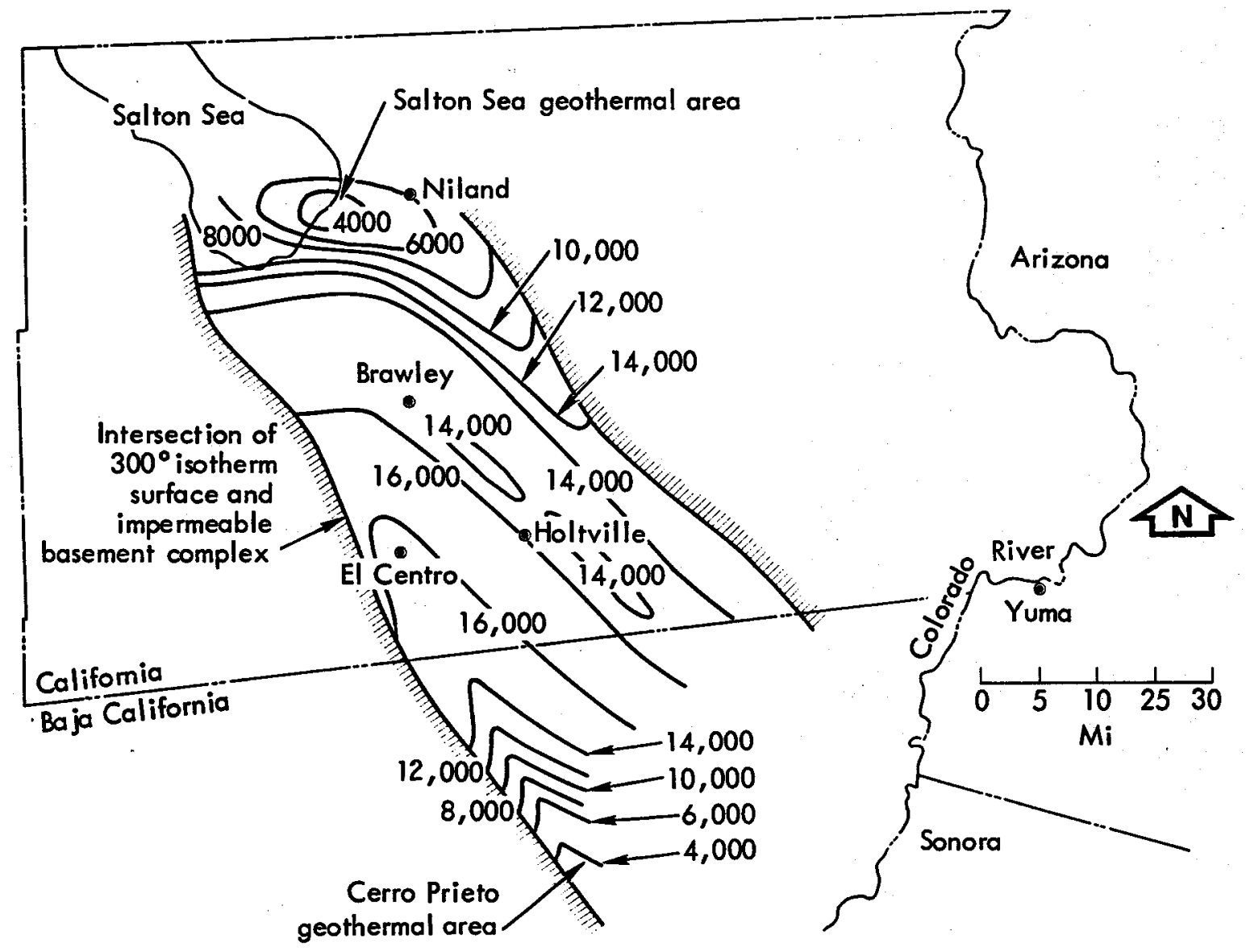

Fig. 4. Salton Trough-surface of $300^{\circ} \mathrm{C}$ isotherm.

enormous. Although a value of this volume has not been computed for the entire Imperial-Mexicali Valleys vicinity, we have made an estimate for that part that constitutes the drilled portion of the Salton Sea geothermal area. To a first approximation, this area includes a volume of rock with brines $>300^{\circ} \mathrm{C}$ on the order of $36 \mathrm{sq} \mathrm{mi}$ in areal dimension and on the order of $2 \mathrm{mi}$ in height. Assuming that the average porosity of this rock volume is $10 \%$ (Ref. 11), the storage volume in the drilled portion of the reservoir amounts to $100 \times 10^{10} \mathrm{ft}^{3}$. This estimate compares with Helgeson's ${ }^{8} \mathrm{fig}$ ure of $5.0 \times 10^{10} \mathrm{ft}^{3}$, made on the basis of well production tests. * To appreciate the significance of this volume it is instructive to compare it with production achieved in one year from a particular well in the area. Otte ${ }^{13}$ reports that the River Ranch well produced $\sim 4.5 \times 10^{6}$ barrels of fluids $\left(25 \times 10^{6} \mathrm{ft}^{3}\right)$ in a year.

\footnotetext{
*Although the Salton Sea geothermal area may justifiably be assigned a larger volume by defining its limits differently than "the drilled portion," for our purposes it is sufficient to point out the very large resource base contained in the drilled portion. If we were to define the Salton Sea geothermal area as the rock volume with brine in excess of $300{ }^{\circ} \mathrm{C}$ and with its upper surface more shallow than $10,000 \mathrm{ft}$ below sea level, then its volume is on the order of $700 \times 10^{10 \mathrm{ft}^{3}}$.
} 
At this yearly rate, a single well like the River Ranch well would exhaust the 100 $\times 10^{10} \mathrm{ft}^{3}$ of brine in $40,000 \mathrm{yr}$. Assuming that any new well penetrating the drilled portion of the Salton Sea geothermal area will flow at an average yearly rate of $12.5 \times 10^{6} \mathrm{ft}^{3} / \mathrm{yr}$ for $20 \mathrm{yr}$, a system of 4000 such wells would be required to exhaust the $100 \times 10^{10} \mathrm{ft}^{3}$ of brine. It appears reasonable, therefore to conclude that the Salton Sea geothermal area reservoir could produce satisfactorily over the 20-yr time span needed to justify the costs of construction of electric power plants. If 4000 wells were drilled, each with a $1 / 2-\mathrm{ft}^{2}$ cross-sectional area, they should theoretically be capable of supporting a $92,000-\mathrm{MW}$ capacity for $20 \mathrm{yr}$. Inasmuch as the present total electrical capacity of the United States is about $340,000 \mathrm{MW}$, it is clear that the Salton Sea geothermal area, as defined by drilling to date, is a very significant natural energy resource.

\section{CHEMICAL COMPOSITION OF'THE BRINES}

Table 1 lists five analyses of chemical constituents produced in the brines. Other data are also available. ${ }^{8,12}$ Data from Helgeson (Column 2) are for brines with temperatures $>300^{\circ} \mathrm{C}$; presumably

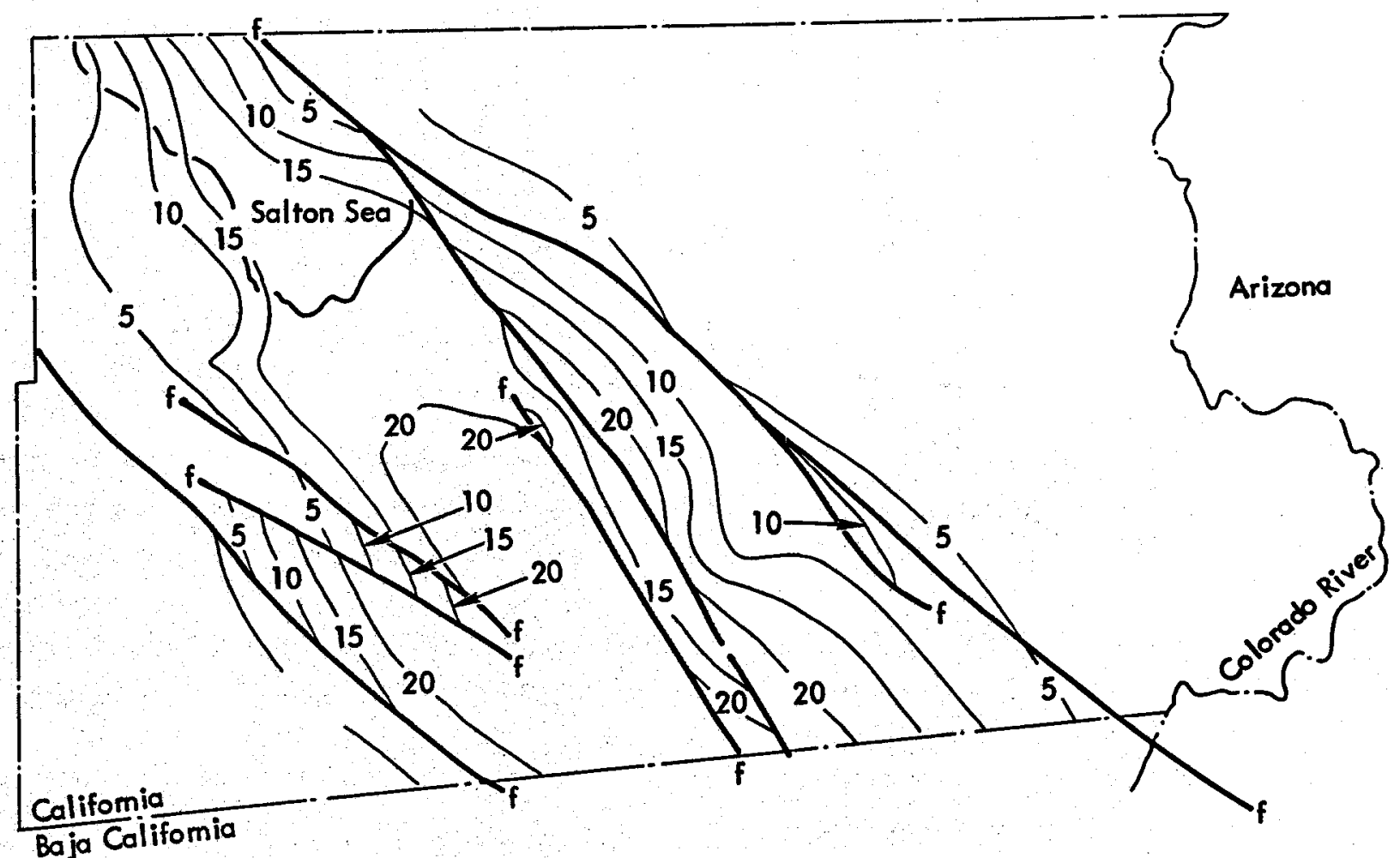

- 10- Contour on basement surface $\times 10^{3}$ feet below sea level

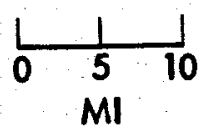

\section{$f \longrightarrow f$ Fault offseting basement surface}

Fig. 5. Depth to basement complex, Imperial Valley-Salton Sea area. After Ref. 10. 
Table 1. Analyses of water from geothermal wells at Salton Sea geothermal area, Cerro Prieto, and Yuma, Arizona, vicinity. From Ref. 8.

\begin{tabular}{|c|c|c|c|c|c|}
\hline Element & Well 39 & $\frac{\text { Niland }}{\text { Well } 36}$ & Well 57 & $\begin{array}{c}\text { Cerro } \\
\text { Prieto } \\
\text { M } 3\end{array}$ & $\frac{\text { Arizona }}{\text { Musgrove } 1}$ \\
\hline Sodium & 50,400 & 53,000 & 10,600 & 5,610 & $141^{a}$ \\
\hline Potassium & 17,500 & 16,500 & 1,250 & 1,040 & - \\
\hline Calcium & 28,000 & 27,800 & 1,130 & 320 & 148 \\
\hline Lithium & 215 & 210 & 40 & 14 & - \\
\hline Magnesium & 54 & 10 & 74 & $-b$ & 43 \\
\hline Strontium & 400 & 440 & 85 & 27 & - \\
\hline Barium & 235 & 250 & 3 & 57 & - \\
\hline Rubidium & 135 & 70 & - & $-b$ & 一 \\
\hline Cesium & 14 & 20 & - & $-b$ & - \\
\hline Iron & 2,290 & 2,000 & 0.7 & $-b$ & - \\
\hline Manganese & 1,400 & 1,370 & 6.4 & $-b$ & - \\
\hline Lead & 102 & 80 & - & $-b$ & - \\
\hline Zinc & 540 & 500 & 一 & $-b$ & - \\
\hline Silver & - & - & - & 0.05 & - \\
\hline Copper & 8 & $-b$ & 一 & 0.09 & - \\
\hline Silica & 400 & 400 & 120 & $-b$ & 18 \\
\hline Chloride & 155,000 & 155,000 & 19,700 & 9,694 & 188 \\
\hline Boron & 390 & 390 & 100 & $12^{\mathrm{c}}$ & - \\
\hline Fluoride & 15 & $-^{0}$ & 1 & 0.88 & - \\
\hline Sum of sulfur & $-\mathrm{b}$ & 30 & - & $\approx 10$ & - \\
\hline Dissolved solids & 258,973 & 259,000 & 34,800 & $\approx 17,000$ & 1,000 \\
\hline
\end{tabular}

they are also for Columns 1,3 , and 4 . The analysis in Column 5 is thought to be from cooler water. It is clear that the brines are very saline. Furthermore, there are indications of a spatial variation in salinity (cf. data from Arizona with data from the Salton Sea geothermal area). Elders et al. suggest that, based on electrical resistivity studies, a regional 'salinity gradient exists such that salinity is lowest near the Colorado
River near Yuma (Column 5) and increases northwestward toward the Salton Sea (Columns 1-3). ${ }^{12}$ Helgeson notes that salinity varies with depth and argues on theoretical grounds that salinities in the Salton Sea geothermal area increase sharply to depths of 3000 to $4000 \mathrm{ft}$ and then maintain values in the 250,000 to 350,000 ppm range. 8

Otte reports other important features of the geochemistry of the brines system. 
The chemical composition of the brine produced over a period of one year in the River Ranch well was essentially unchanged. ${ }^{13}$ This observation indicates that the spatial variation of salinity in the reservoir tapped by the River Ranch well is small. This observation is consistent with Helgeson's conclusion that salinities are more or less constant in the Salton Sea geothermal area at depths $>3000$ to $4000 \mathrm{ft}$ (Ref. 8). Otte also indicates that the permeability of the near-bore vicinity of a well can be adversely affected by pressure drawn down at the wellbore during production. Reduction in the formation fluid pressure can cause the fluids to flash into steam and lead to precipitation of minerals in the pore space. He states that spacing of wells and production rates of geothermal wells in the Salton Sea geothermal area should be planned to minimize or prevent such precipitation. 13

\section{FLUID PRESSURES OF THE BRINES}

Helgeson reports information on fluid pressures for the brines in the Salton Sea geothermal area. ${ }^{8}$ Information on six wells indicates that pressures in the fluid are "normal" hydrostatic for this area. Presumably this conclusion is applicable to other areas in the Coachella-ImperialMexicali Valleys vicinity. Figure 6 summarizes Helgeson's data.

Figure 7, which is also from Helgeson, summarizes the relationship between the temperatures and pressures of the brines at any depth in certain wells and the temperatures and pressures required to change the liquid brine to steam. If the pressure at a point in a well is reduced

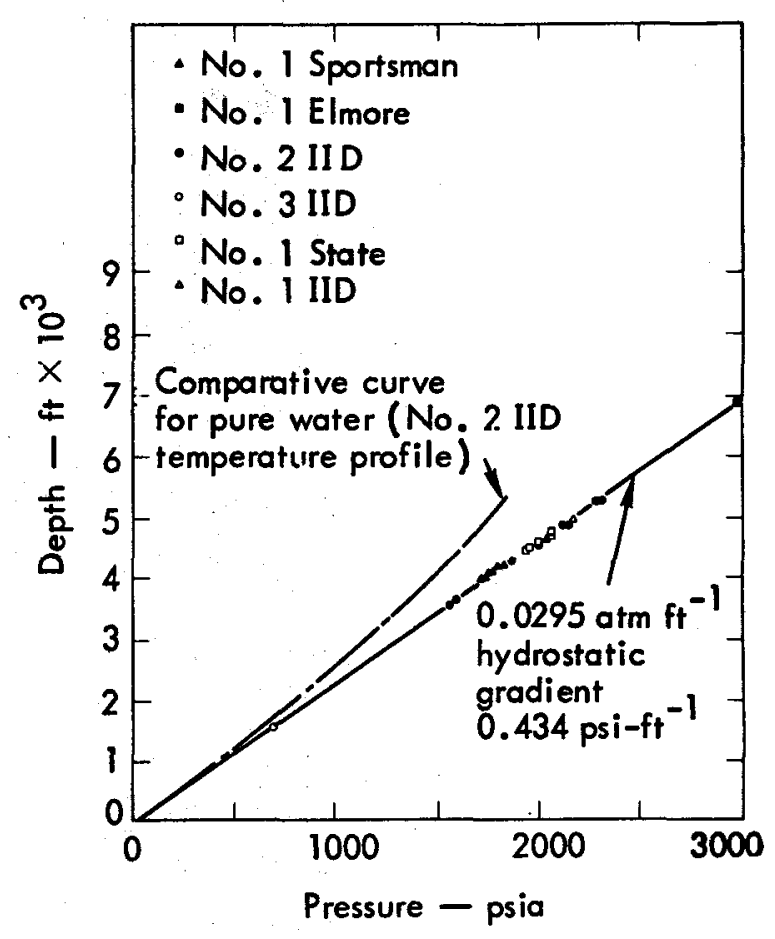

Fig. 6. Pressure measurements at casing perforations in six geothermal wells. After Ref. 8.

sufficiently by artificial means, the brine will flash. Subsequently, because of the reduced hydrostatic head in the well to that point in the reservoir, the reservoir should flow a two-phase mixture to the well head.

\section{ESTIMATES OF PRODUCTION CAPABILITY OF WELLS}

Production data for four wells other than the River Ranch well are shown in Fig. 8. Otte's report for the River Ranch well ${ }^{13}$ and Helgeson's for the entire Salton Sea geothermal area ${ }^{8}$ are consistent. Productivities are high. Helgeson notes that no change in enthalpy, temperature, or brine composition occurred during sustained production tests (as long as $18 \mathrm{mo}$ ) of the various wells. Helgeson further indicates that natural fractures 


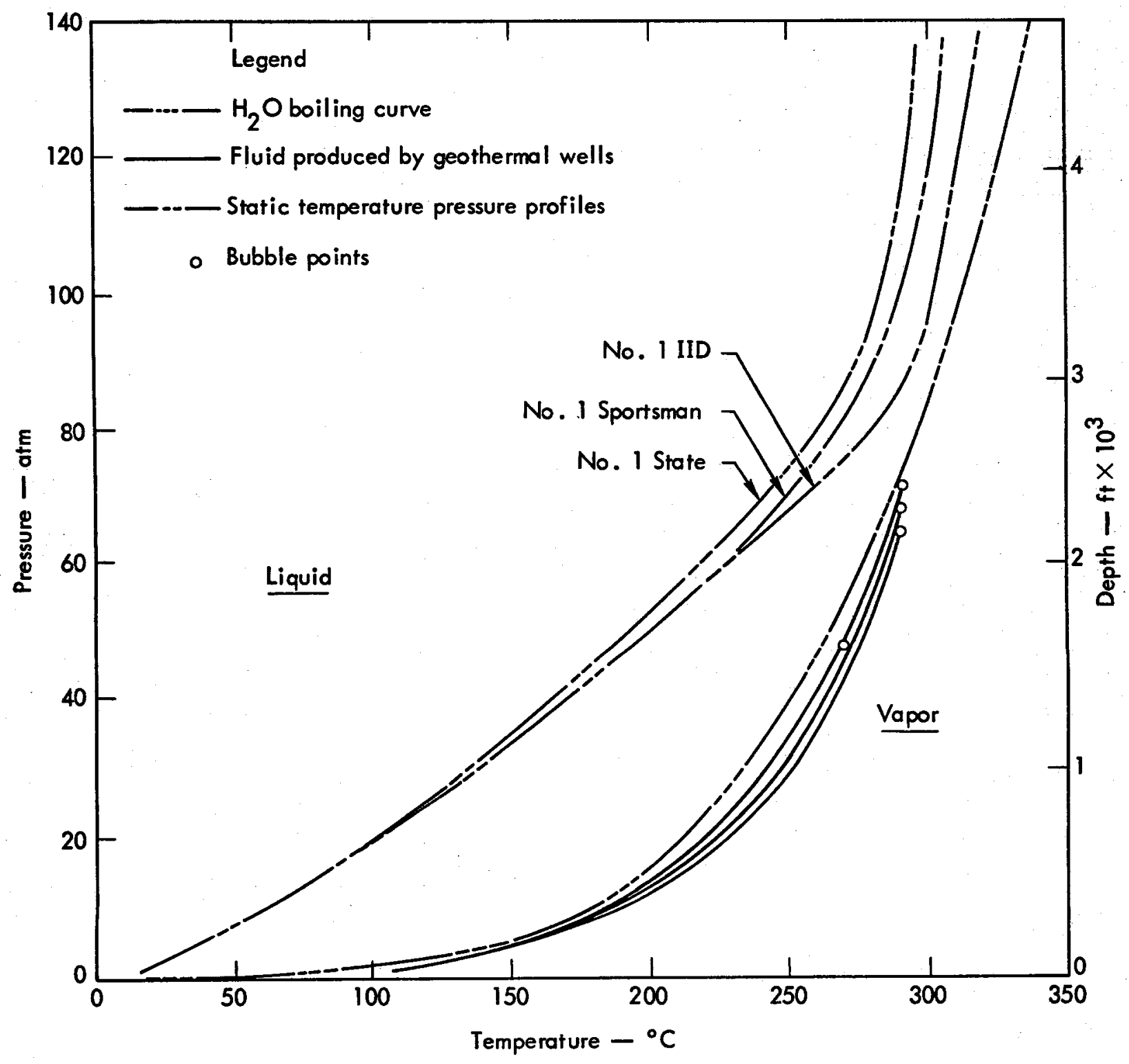

Fig. 7. Pressure-temperature diagram. After Ref. 8.

may serve as the major conduits for production of the brines. ${ }^{8}$ Although these fractures drain the interstitial pore space and are not the principal storage volume, they have high permeabilities. They are probably the cause of high production capacities. It may be very important that they be intersected by a well if the well is to produce at the rates noted so far. To date such intersection has not been difficult, so flow capacities to meet the described power plant requirements should pose no problem.

Another point about flow capacities of wells in the area is that Otte reports no problems in injecting waste brine back into the system. In fact, injection capacity exceeded production capacity. ${ }^{13}$ 


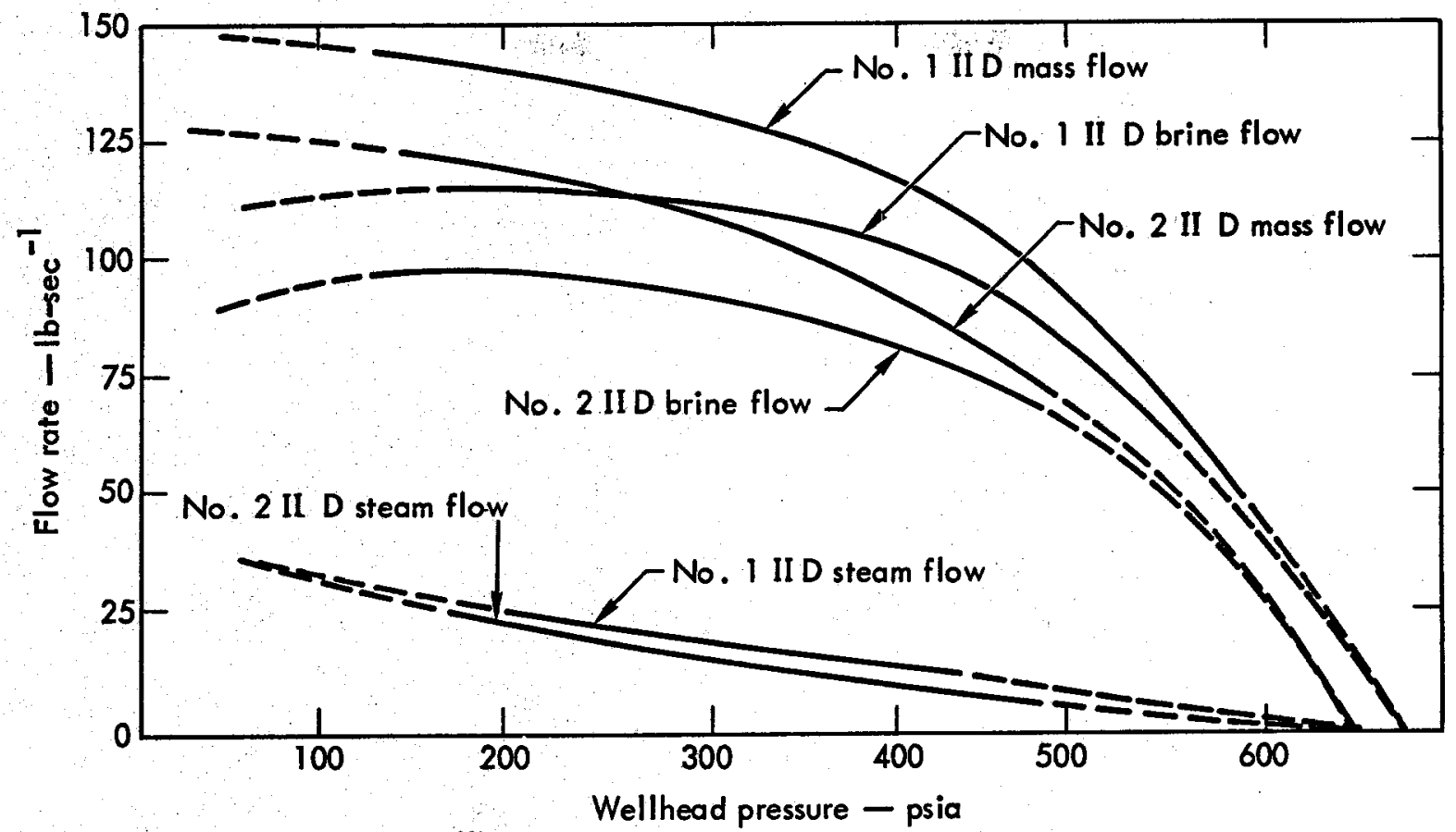

a. As a function of wellhead pressure.

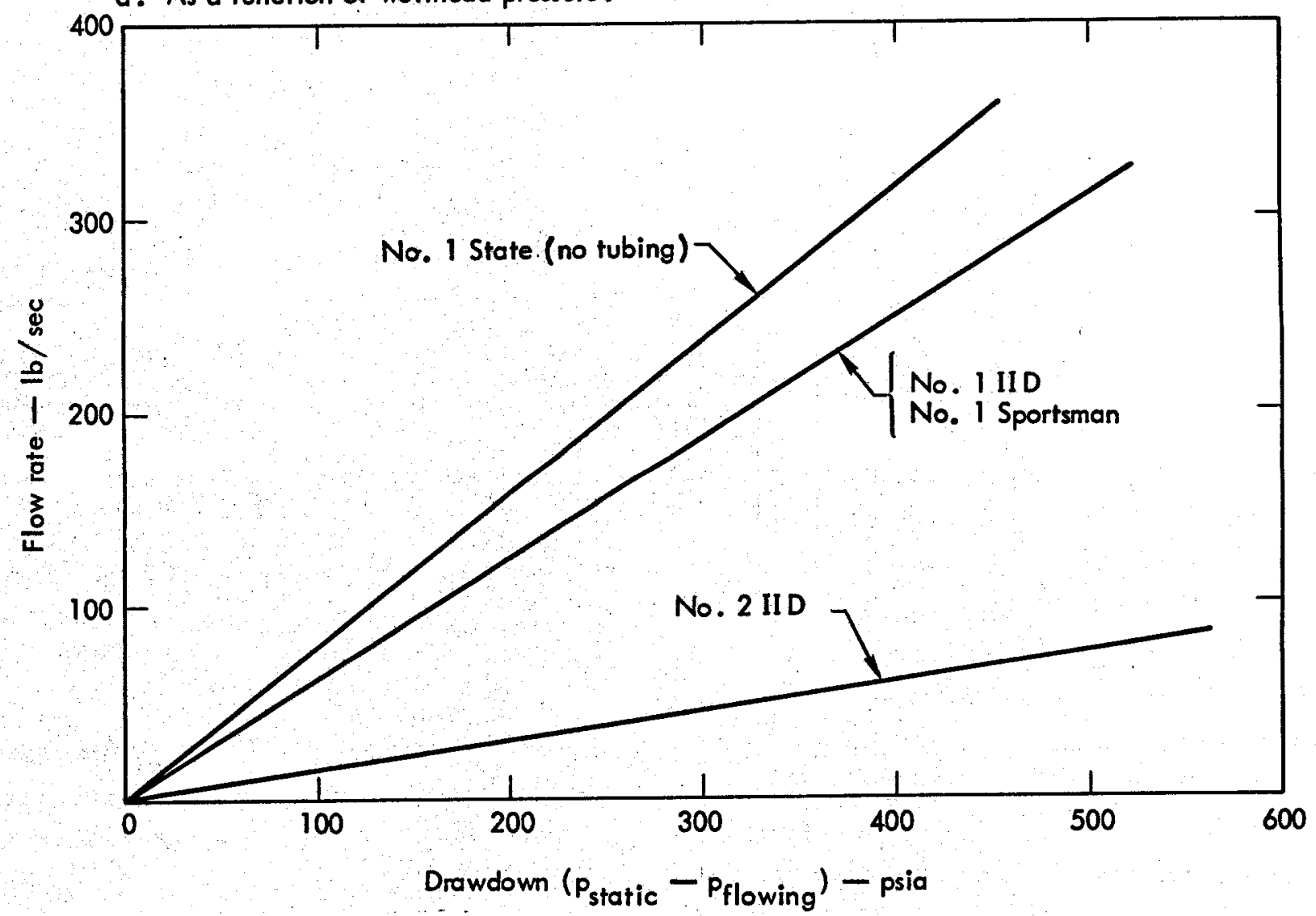

b. As a function of drawdown pressure

Fig. 8. Geothermal well flow rates. 
MECHANISM FOR GENERATING GEOTHERMAL HEAT IN THE

SALTON TROUGH

The most important point regarding the mechanism for generating geothermal heat in the Salton Trough is that the "motor" driving the system is of global proportions. It is virtually certain that it will continue to maintain the fundamental geothermal system of the Salton Trough for an indefinitely long period of time despite any exploitation of this resource. The regeneration rate is presently unknown, however.

There are two parts to the mechanism for developing hot brines in the Salton Sea geothermal area: flow of water into and its accumulation in the Imperial ValleySalton Sea area, and heating the water and concentrating the dissolved solids in the brine. Water input to the brine system of the Salton Sea geothermal area appears to come from two sources. Most recharge is from run-off from nearby mountains, ${ }^{10}$ and some may come from the Colorado River. Various workers (e.g., Helgeson ${ }^{8}$ ) argue about the relative roles of these sources, especially insofar as they affect the chemical composition of the brines.

Recharge water in the Salton Sea geothermal area that descends to depths greater than $\sim 3000 \mathrm{ft}$ is warmed by heat normally associated with the earth's mantle. This water apparently becomes part of a circulating convection cell (see Fig. 9d) that taps this very deep heat source. 12

As noted earlier, the Salton Trough is the topographic extension of the Gulf of
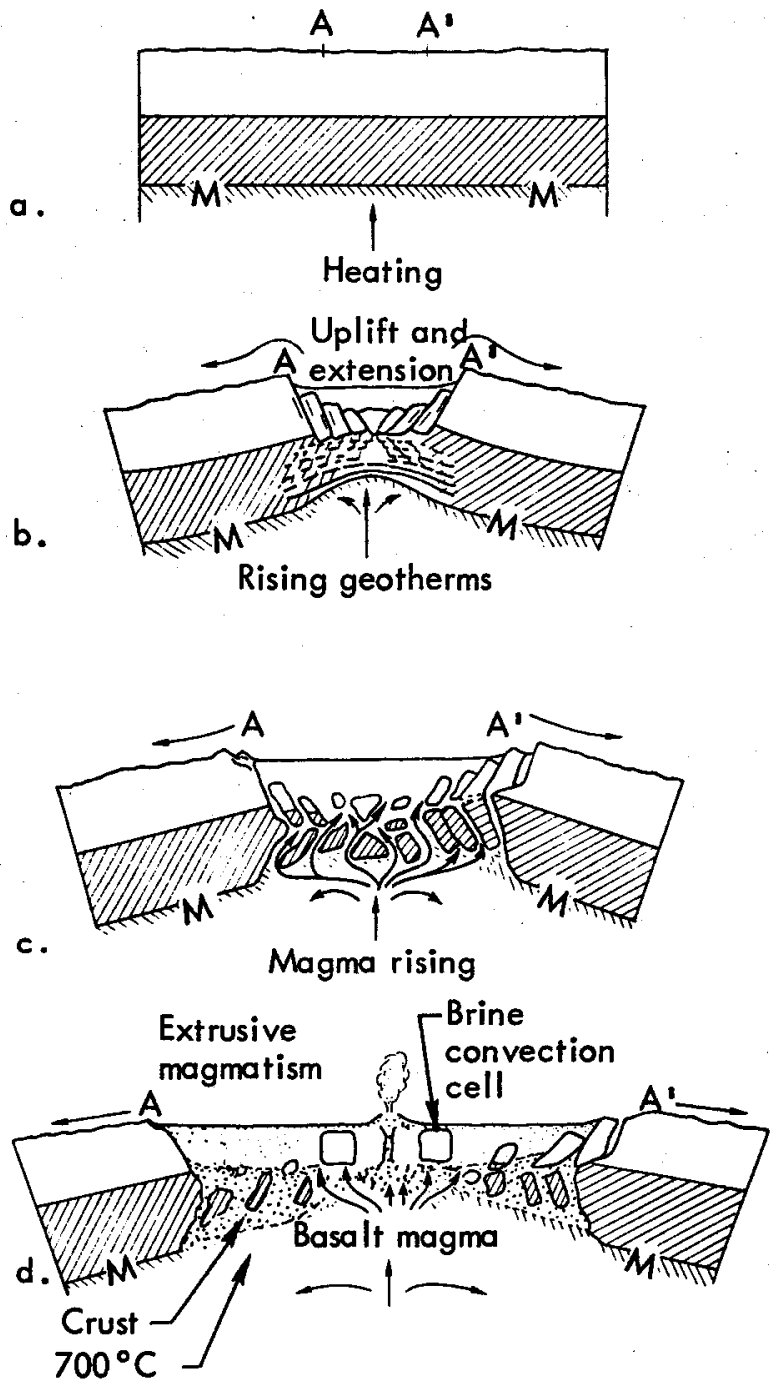

Fig. 9. Model of rifting and magma generation during growth of the Salton Trough. The sections are drawn parallel to major strikeslip faults in the area. In a, two layers of crust overlie a hot zone in the mantle. $M$ is Mohorovicic discontinuity and $A$ and $A^{\prime}$ are reference points for later movements. In $b$, there is upward and lateral expansion; a trough is initiated and partly filled in by sediments. In $c$, the widening trough is invaded by basaltic magma; metamorphism of the sediments and gravitational sliding of the tilted walls occur. In d, melting of the basement and extrusion of rhyolitic magma occur. After Ref. 12 . 


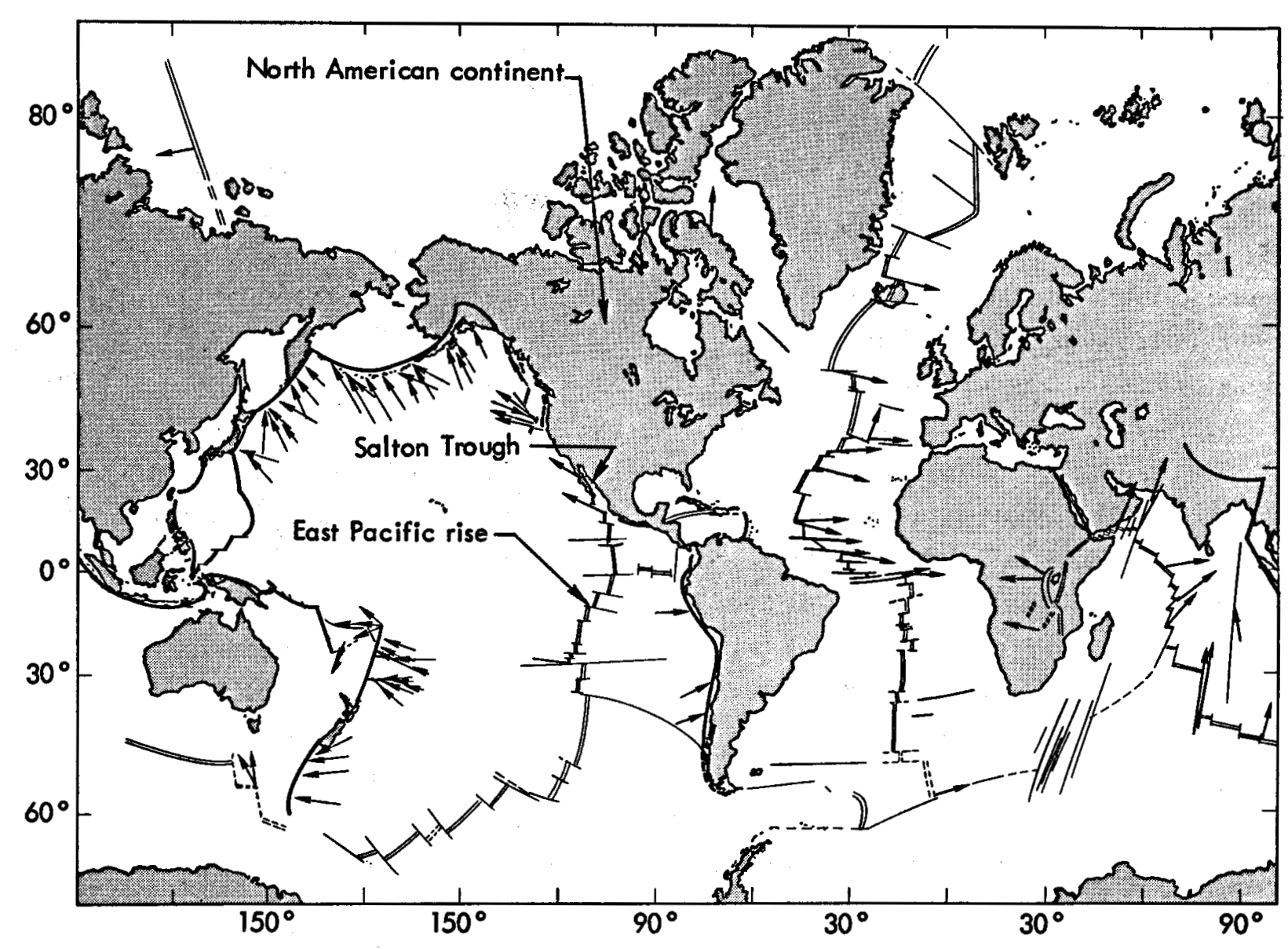

Fig. 10. Major ridges, trenches and transform faults, identified as part of the "new global tectonics" hypothesis. From Ref. 14 .

California. Both are, to a first approximation, astride the East Pacific Rise, an oceanic ridge of global importance.

Ridges such as this are the principal zones separating the earth's crust and upper mantle and are the sites of upwelling hot mantle rocks. The East Pacific Rise intercepts the North American continent at the Salton Trough, as shown in Fig. 10 (Ref. 14). Elders et al. describe the progression of events following the initial interception, ${ }^{12}$ and Fig. 9 shows their interpretation. Figures $9 b$ and $9 d$ clearly show that the ridge allows a great deal of heat to be transferred to the base of the sequence of rocks filling in the Salton Trough. Not only do the brines become hot (note the convection cell in Fig. 9d), but volcanism also develops. Volcanism of this sort is seen at the south end of the Salton Sea, in the Obsidian Buttes area. 


\section{Thermodynamic Analysis}

\section{CALCULATIONS OF WELL FLOW}

Since we need to know expected wellhead conditions to evaluate any of the conversion systems, it is important to assess the factors governing fluid flow up a well for given downhole conditions. We selected reservoir conditions typical of the Imperial Valley area, as are shown in Figs. 6-8. The calculations, then, are for a brine deposit initially at $300^{\circ} \mathrm{C}$ at a depth of $5100 \mathrm{ft}$ with a reservoir pressure of 2213 psia. Since the saturation pressure is 1240 psia for a temperature of $300^{\circ} \mathrm{C}$, the brine is in the compressed liquid regime. The difference in enthalpy of the compressed liquid and the saturated liquid is only $\sim 1 \%$ and is neglected, so the enthalpy content of the brine is $\sim 577 \mathrm{Btu} /$ $\mathrm{lb}$, the value for saturated liquid at $300^{\circ} \mathrm{C}$ and 1240 psia. Once the well has been induced to flow by initial pumping, it will continue to flow unaided because of the decreased column density as the water flashes to steam, yielding a two-phase mixture of liquid and vapor at the wellhead.

We can estimate the location in the well at which flashing starts by considering a column of liquid of height $z_{o}$ subject to saturation pressure $p_{s}$ at the top and downhole pressure at the bottom. Neglecting the change in velocity and frictional losses, a force balance on the column gives

$$
\gamma z_{o}=p_{r}-p_{d}-p_{s}
$$

where $p_{r}$ is the reservoir pressure, $p_{d}$ is the drawdown pressure, and $\gamma$ is the specific weight of the fluid. Figure $8 b$ shows that the drawdown pressure is proportional to the flow rate $w$, and for two of the four wells the relationship is

$$
\mathrm{p}_{\mathrm{d}}=\mathrm{kw} \simeq 1.6 \mathrm{w}
$$

where $p_{d}$ is in psia and $w$ is in units of lb/sec. Substituting Eq. (2) into Eq. (1) and setting $z_{0}=0$, we see that when

$$
w \geq \frac{p_{r}-p_{s}}{1.6}=608 \mathrm{lb} / \mathrm{sec} \text {, }
$$

flashing will occur at the well bottom. For flow rates less than this, flashing will occur at some position up the pipe defined by

$$
z_{0}=\frac{144\left(p_{r}-p_{s}-1.6 w\right)}{\gamma}
$$

where $z_{0}$ is in $\mathrm{ft}$ and at $300^{\circ} \mathrm{C}$ the density, $\gamma$, is $55.5 \mathrm{lb} / \mathrm{ft}^{3}$. For example, a flow rate of $250 \mathrm{lb} / \mathrm{sec}\left(500 \mathrm{lb} / \mathrm{sec} / \mathrm{ft}^{2}\right.$ for a 9-5/8-in. casing) gives a flash point height of $\sim 1487 \mathrm{ft}$ where temperature and pressure are $\sim 300^{\circ} \mathrm{C}$ and 1240 psia and decrease further as flashing occurs up the well.

It has been observed that wellhead temperature and pressure of wells flowing steadily for 18 mo remained constant during production. ${ }^{8}$ This evidence plus substantiating heat transfer calculations indicate that the flow can be considered adiabatic. ${ }^{8}$ Fluid pressures up the pipe, then, can be calculated by numerical solution of the momentum and continuity equations, assuming an adiabatic expansion and using the corresponding pairs of 
$(p, v)$ values taken from the Steam Tables ${ }^{15}$ for the integration. The momentum equation is

$$
v d p+\frac{V d V}{g}=-\left(1+\frac{f V^{2}}{2 g D}\right) d z
$$

Conservation of mass requires that

$$
\mathbf{w}=\mathrm{AV} / \mathrm{v} \text {. }
$$

Combining Eq. (6) for $A=$ constant with Eq. (5) gives the flow equation in pressure, volume, and position as

$$
\begin{aligned}
& \int_{v_{1}}^{v} \frac{v d p}{1+\frac{f}{2 g D}\left(\frac{w}{A}\right)^{2} v^{2}}+\frac{1}{g}\left(\frac{w}{A}\right)^{2} \\
& \quad \times \int_{v_{0}}^{v} \frac{v d v}{1+\frac{f}{2 g D}\left(\frac{w}{A}\right)^{2} v^{2}}=\int_{z_{0}}^{z}-d z
\end{aligned}
$$

where

$$
\begin{aligned}
& v=\text { specific volume, } \mathrm{ft}^{3} / \mathrm{lb} \\
& \mathrm{p}=\text { pressure, psia } \\
& \mathrm{v}=\text { velocity, fps } \\
& z=\text { height above wellbottom, ft } \\
& z_{0}=\text { height where flashing occurs, } \mathrm{ft} \\
& \mathrm{D}=\text { diameter of production tubing, } \mathrm{ft} \\
& \mathrm{A}=\text { area of production tubing, } \mathrm{ft} \\
& \mathrm{w}=\text { weight flow rate, } 1 \mathrm{~b} / \mathrm{sec} \\
& \mathrm{f}=\text { pipe friction factor } \\
& \mathrm{g}=\text { acceleration of gravity, } \\
& \quad 32.2 \mathrm{ft} / \mathrm{sec}^{2}
\end{aligned}
$$

Numerical integration of Eq. (7) gives the pressure as a function of the height above the flash point, $\left(z-z_{0}\right)$, for a given fric- tion factor and areal flow rate, w/A. Once the wellhead pressure is known, reference to the Steam Tables ${ }^{15}$ provides the other state variables of the wellhead product.

We have made numerous calculations for a range of friction factors. Figure 11 shows the results for some of these calculations for various areal flow rates from 250 to $750 \mathrm{lb} / \mathrm{sec} / \mathrm{ft}^{2}$ and for friction factors of 0.02 and $\mathbf{0 . 0 4}$. We chose a diameter of $0.8 \mathrm{ft}$ (nominal 9-5/8-in. i.d.) for all calculations. From Eq. (4), we calculated $z_{o}$ for the various flow rates. By assuming a well depth of $5100 \mathrm{ft}$, we can calculate the value $\left(z-z_{0}\right)$ for each flow rate corresponding to the values chosen for $w / A$ for the case $A=0.5 \mathrm{ft}^{2}$. The locus of these points for $\left(z-z_{0}\right)$, is shown by the dashed lines in Fig. 11. Intersection of these lines with the pressure drop curves gives the wellhead pressure for the respective conditions of flow rate and friction factor for the chosen well depth of $5100 \mathrm{ft}$.

It is clear that the flow is friction dominated. Since we do not know the actual value of the friction factor, we must choose a desired $\mathrm{w} / \mathrm{A}$ and find the pressure drop curve that intersects the locus of points $\left(z-z_{\rho}\right)$. An areal flow rate of $500 \mathrm{lb} / \mathrm{sec} / \mathrm{ft}^{2}$ gives a wellhead pressure of 600 psia for a friction factor of 0.02 and $\sim 360$ psia for a friction factor of 0.04. Since a friction factor of $\mathbf{0 . 0 4}$ may be more realistic for actual operating conditions because of scaling, we will select 360 psia as a conservative estimate of wellhead pressure. This value of pressure, then, fixes the wellhead characteristics as summarized in Table 2. 


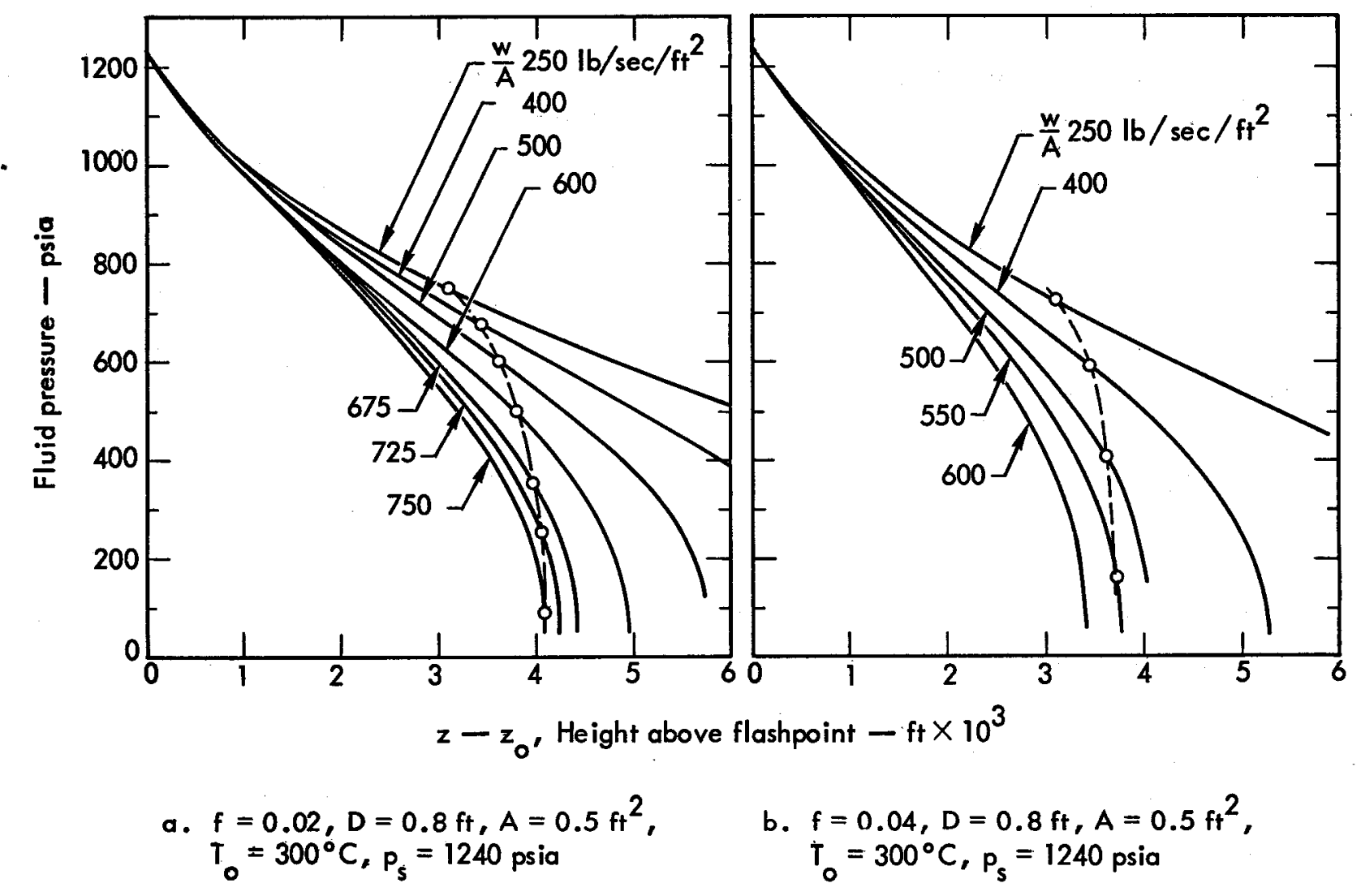

Fig. 11. Well characteristics.

Table 2. Wellhead product characteristics.

Pressure, p

Volume, $v$

Temperature, $\mathrm{T}$

Enthalpy, h

Quality, $x$

Depth

Flow rate, w/A

Velocity, $\mathrm{V}=\mathrm{wv} / \mathrm{A}$

Vapor volume/liquid

volume, $v_{v} / v_{L}$
360 psia

$0.259 \mathrm{ft}^{3} / 1 \mathrm{~b}$

$434^{\circ} \mathrm{F}$

$562.5 \mathrm{Btu} / \mathrm{lb}$

0.189

$5100 \mathrm{ft}$

$500 \mathrm{lb} / \mathrm{sec} / \mathrm{ft}^{2}$

$130 \mathrm{ft} / \mathrm{sec}$

16

These values are generally consistent with those reported for the Cerro Prieto wells. ${ }^{9}$ Moreover, the flow rate for the $1 \mathrm{IID}$ well is $125 \mathrm{lb} / \mathrm{sec}$ for a wellhead pressure of $360 \mathrm{psia}$ (see Fig. 8a). Since that well had a 7-5/8-in. o.d. production

casing, ${ }^{16}$ the areal flow rate is $\sim 475 \mathrm{lb} /$ $\mathrm{sec} / \mathrm{ft}^{2}$. This too is consistent with our choice of a flow rate of $500 \mathrm{lb} / \mathrm{sec} / \mathrm{ft}^{2}$ and a wellhead pressure of 360 psia. Therefore, we shall consider the calculated wellhead characteristics shown in Table 2 to be credible and shall use them as the basis for evaluation of the proposed system and its comparison with the flashed steam and binary fluid systems. The comparison with the former is most significant since that is the only one operational.

\section{THE TOTAL FLOW SYSTEM}

In the total flow system, the wellhead product from several whipstocked wells at 360 psia is fed directly through 
converging-diverging nozzles to convert the thermal energy in the mixture to kinetic energy to operate the turbine (see Fig. 12). The maximum power output is given by

$$
P=w V^{2} / 2 g
$$

Power output is greatly increased by lowering the turbine chamber pressures, thereby increasing velocity. The steam velocity is related to the total enthalpy change through the nozzle such that

$$
\mathrm{v}^{2}=\mathrm{v}_{\mathrm{o}}^{2}+2 \mathrm{gJ \Delta h}
$$

where

$$
\begin{aligned}
\mathrm{V}_{\mathrm{O}}= & \text { initial fluid velocity at the } \\
& \text { nozzle entrance in fps } \\
\mathrm{J}= & \text { mechanical equivalent of } \\
& \text { heat }=778 \mathrm{ft}-\mathrm{lb} / \mathrm{Btu}
\end{aligned}
$$

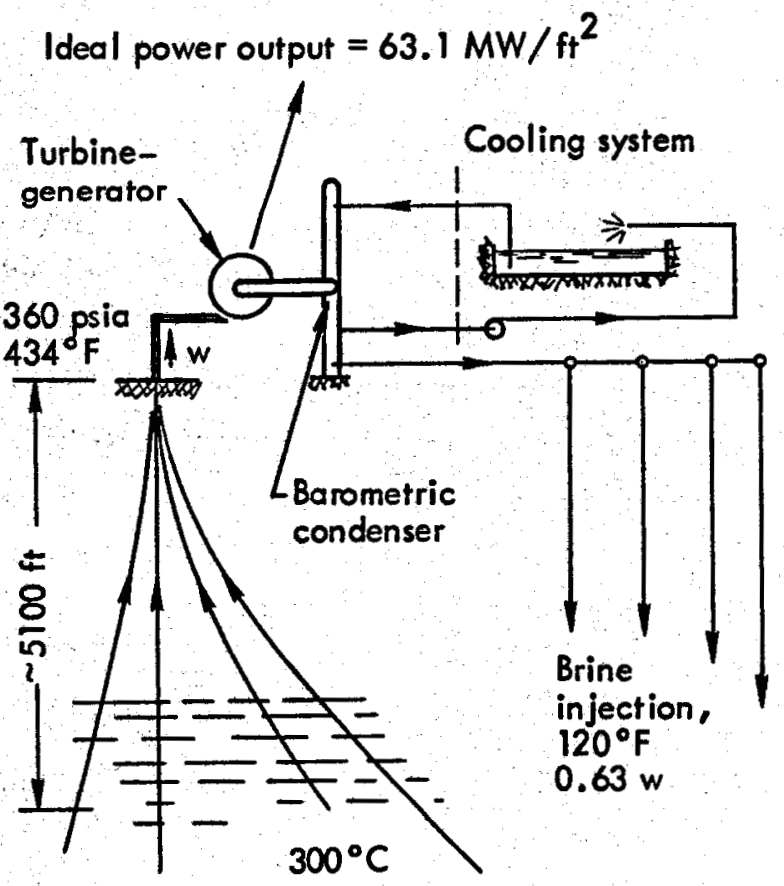

Fig. 12. The total flow concept.

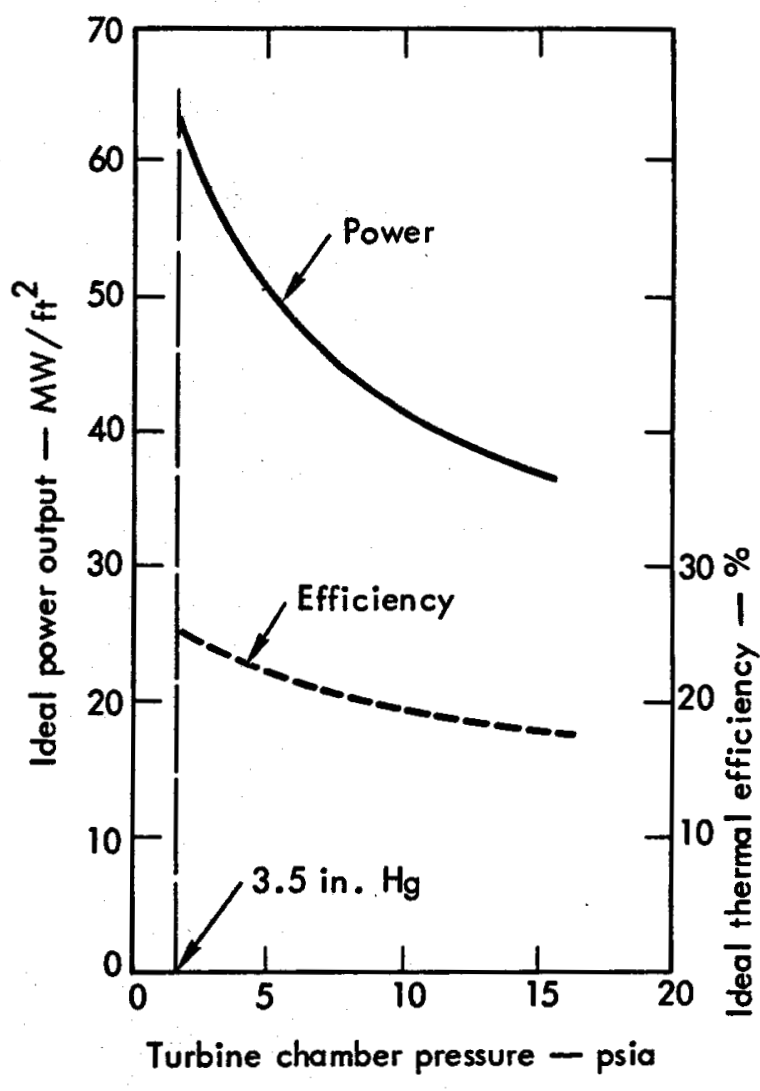

Fig. 13. Ideal power output from the total flow system.

$$
\begin{aligned}
\Delta h= & \text { enthalpy drop through the } \\
& \text { nozzle in Btu } / \mathrm{lb} .
\end{aligned}
$$

The enthalpy drop is calculated by subtracting the enthalpy at the nozzle exit pressure from the inlet enthalpy (562 Btu/lb). The exit value is found by assuming an isentropic expansion to the turbine operating pressure, which is set by the condensing temperature. For the wellhead conditions shown in Table 2 , the ideal velocity from $\mathrm{Eq}$. (9) is $\sim 2400$ fps for a condenser temperature of $120^{\circ} \mathrm{F}$ at $3.5 \mathrm{in} . \mathrm{Hg}$. The ideal power output in terms of $\mathrm{MW} / \mathrm{ft}^{2}$ of wellbore area is shown in Fig. 13 as a function of condenser pressure. For a backpressure of $3.5 \mathrm{in}$. $\mathrm{Hg}$ at $120^{\circ} \mathrm{F}$ - a practical value for this application - the ideal power output 


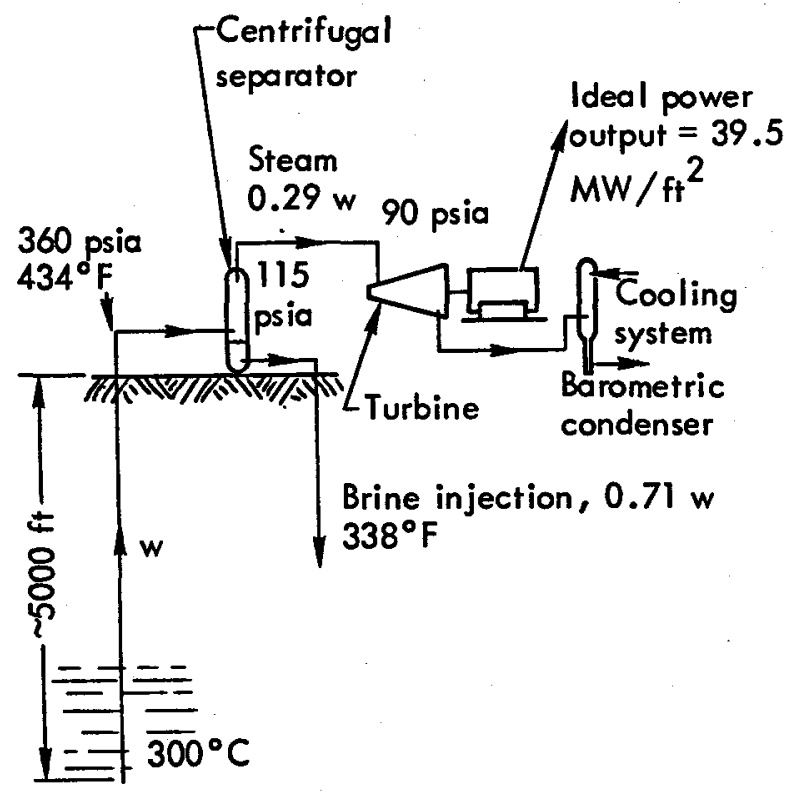

Fig. 14. The flashed steam system.

is $63.1 \mathrm{MW} / \mathrm{ft}^{2}$. For other wellhead conditions, the ideal power output will, of course, have other values.

The point here is that the thermal energy in the entire wellhead product is converted to kinetic energy which is then converted to electrical energy by an impulse turbine. The advantage of this method is that most of the thermal energy is used for power production. In comparison the flashed steam system uses only the energy contained in the flashed vapor to drive a turbine, with the remaining energy discarded with the separated hot brine.

The ideal power output of $63.1 \mathrm{MW} / \mathrm{ft}^{2}$ is the output from a perfect turbine and an isentropic nozzle. The actual power output, however, will be less because of nonideal flow in the nozzle and losses in the turbine. These are represented by a turbine wheel efficiency $e_{w}$ and a velocity coefficient $\eta$ in the nozzle such that $\mathrm{V}_{\text {actual }}=\eta \mathrm{V}$. Hence, the actual power output in $\mathrm{MW} / \mathrm{ft}^{2}$ will be

$$
\mathrm{P}_{\mathrm{TF}}=63.1 \mathrm{e}_{\mathrm{w}} \eta^{2}
$$

The wheel efficiency should be $\sim 0.9$, and evidence exists that indicates that nozzle coefficients of $\sim 0.9$ are not unreasonable even for the two-phase flow, in which the mass of vapor is $20 \%$ of the total, expected for this application. Hence a value of 0.73 for the quantity $e_{w} \eta^{2}$ is a reasonable design goal and would lead to an expected power output of $46.0 \mathrm{MW} / \mathrm{ft}^{2}$ of well cross section.

\section{THE FLASHED STEAM SYSTEM}

In the flashed steam concept (in use at Cerro Prieto), the liquid salt-containing brine is separated from the relatively pure vapor at the wellhead and power is recovered from the saturated steam alone (see Fig. 14). The wellhead mixture of hot brine and vapor is fed first through a centrifugal separator that forms additional vapor at the lower operating pressure. The vapor is drawn off to drive a steam turbine and the remaining brine is disposed of by injection. Figure 15 gives the ideal power output as a function of separator pressure. Note that this is for the same assumed well performance conditions as used in the previous example. The curves are calculated from the Steam Tables ${ }^{15}$ by starting with the wellhead conditions ( $p$, $T, h, S, x$ in Table 2), selecting a lower pressure, and calculating the steam quality $x$ for either an isenthalpic or isentropic process. We assume here that the process is isenthalpic so that the maximum power output of $39.5 \mathrm{MW} / \mathrm{ft}^{2}$ occurs at a separator pressure of $\sim 115$ psia. The Cerro Prieto system has 


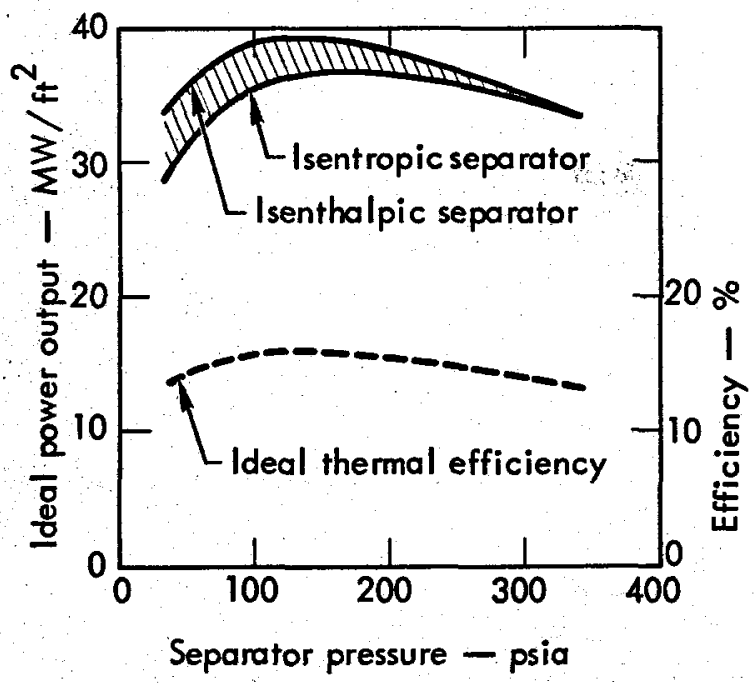

Fig. 15. Ideal power output for a geothermal flashed steam system. Downhole $570^{\circ} \mathrm{F}, 1240$ psia; wellhead $5100 \mathrm{ft}, 434^{\circ} \mathrm{F}, 360$ psia, $\mathrm{x}=0.19$; pressure drop to turbine $20 \%$; turbine exhaust pressure 3.5 in. $\mathrm{Hg}$ (1.73 psia).

a $20 \%$ pressure drop between the separator and turbines that we assume to be representative. Such a drop corresponds to $\sim 15 \mathrm{Btu} / 1 \mathrm{~b}$ loss at 115 psia or a $6 \%$ loss in available power. An additional loss occurs through the turbine as measured by the turbine efficiency $e_{t} \cdot$ Hence, the actual power output in $\mathrm{MW} / \mathrm{ft}^{2}$ to the generator is

$$
P_{\mathrm{FS}}=39.5 \mathrm{e}_{\mathrm{t}}
$$

Since the throttle steam is saturated, excessive moisture during expansion through an axial flow multistage turbine results in decreased turbine efficiencies that are typically 70 to $75 \%$. From the reported operating characteristics of the Cerro Prieto system, ${ }^{9}$ we estimate that the turbine efficiency $e_{t}$ is $\sim 70 \%$. The ideal cycle efficiency shown in Fig. 5 is $\sim 15.8 \%$ and is defined as the ratio of the energy available from the separator to the energy available at the wellhead. The actual thermal efficiency, then, is $0.7(0.158)$, or $11.0 \%$. For comparison, the Carnot efficiency is $34.7 \%$ relative to the wellhead fluid temperature, and $43.7 \%$ relative to the wellbottom temperature.

\section{BINARY FLUID SYSTEMS}

There are a number of variants of the two-fluid system shown schematically in Fig. 1b. In these the hot brine heats a secondary working fluid that drives the turbo-generator system. The brine may be pumped to the surface or allowed to expand and pump itself, as in the other two methods. The secondary working fluid can be any material whose boiling point characteristics are compatible with the lower operating temperature of the turbine. Isobutane and freons have been suggested because they boil at sufficiently low temperatures to operate at the lowest temperature that can be reached with evaporative cooling of water in the atmosphere.

Assuming the same well conditions as the previous two examples, we find that the total heat available in the fluid coming from the well is $\sim 562 \mathrm{Btu} / \mathrm{lb}$. For any heat exchanger

$$
q_{e}=U A \Delta T_{m} F
$$

where $q_{e}$ is the heat transferred to the secondary fluid, $U$ is the overall heat transfer coefficient, $F$ is a correction factor for the exchanger design and is assumed to be unity, and $\Delta \mathrm{T}_{\mathrm{m}}$ is the $\log$ mean temperature difference defined as 


$$
\Delta T_{m}=\frac{\left(\dot{T}_{\mathrm{H} 1}-T_{\mathrm{C} 2}\right)-\left(\mathrm{T}_{\mathrm{H} 2}-\mathrm{T}_{\mathrm{C} 1}\right)}{\ln \frac{\left(\mathrm{T}_{\mathrm{H} 1}-\mathrm{T}_{\mathrm{C} 2}\right)}{\left(\mathrm{T}_{\mathrm{H} 2}-\mathrm{T}_{\mathrm{C} 1}\right)}} .
$$

The temperatures are defined as

$$
\begin{aligned}
& \mathrm{T}_{\mathrm{H} 1}=\text { hot brine input to exchanger } \\
& \mathrm{T}_{\mathrm{H} 2}=\begin{array}{l}
\text { spent brine exit from } \\
\text { exchanger }
\end{array} \\
& \mathrm{T}_{\mathrm{C} 1}=\begin{array}{l}
\text { cold working fluid input } \\
\text { to exchanger }
\end{array} \\
& \mathrm{T}_{\mathrm{C2}}=\begin{array}{l}
\text { hot working fluid output } \\
\text { from exchanger. }
\end{array}
\end{aligned}
$$

The heat exchanger can be designed to make $\mathrm{T}_{\mathrm{C} 2}$ as close to $\mathrm{T}_{\mathrm{H} 1}$ as desired but only at the expense of increasing the area

A. Since heat exchanger costs vary nearly linearly with $A$, cost of transfer of heat varies as the ratio of $q / A$. The heat transferred to the turbine $q$ depends on $\mathrm{T}_{\mathrm{H} 2} \cdot \mathrm{T}_{\mathrm{C} 1}$ is fixed by the ambient atmospheric temperature and humidity, which for the Imperial Valley should be $100^{\circ} \mathrm{F}$. Thus, a trial and error solution, in which $\mathrm{T}_{\mathrm{H} 2}$ is chosen and $\mathrm{T}_{\mathrm{C} 2}$ is calculated, is required. We found the factor $U$ for heat transfer through moderately scaled exchanger tubes from brine to light organic fluids to be on the order of 50 to $100 \mathrm{Btu} /$ $\mathrm{ft}^{2}-\mathrm{hr}{ }^{\circ} \mathrm{F}$.
If the turbine system efficiency is proportional to the Carnot cycle efficiency, then the optimum heat exchanger design must maximize the fraction of the heat used for power generation at the same time the cost of the heat exchanger is minimized. Thus, a maximum of

$$
\frac{\mathrm{q}}{\mathrm{Q}} \cdot \frac{\mathrm{q}}{\mathrm{A}} \cdot\left(\frac{\mathrm{T}_{\mathrm{C2}}-\mathrm{T}_{\mathrm{C1}}}{\mathrm{T}_{\mathrm{C} 2}}\right)
$$

must be found, where $q / Q$ is the ratio of energy transferred to the turbine to the energy in the brine, $Q$.

For the conditions above, $\mathrm{T}_{\mathbf{C 1}}$ and $\mathrm{T}_{\mathrm{H} 2}$ were both found to be optimum at $300^{\circ} \mathrm{F}$ and $\mathrm{A}$ was $\sim 35,000 \mathrm{ft}^{2} / \mathrm{ft}^{2}$ of well. The pumping power is already included since we assumed the well to be operated in the self-pumping mode. An additional fraction of the power must be used to operate the secondary fluid circulation pump. The overall power in $\mathrm{MW} / \mathrm{ft}^{2}$ from a two-fluid system operated as described above was determined to be

$$
\mathrm{P}_{\mathrm{BF}}=40.4 \mathrm{e}_{\mathrm{t}}
$$

Since the secondary fluid must be pumped and power for the pump must be subtracted, we have concluded a value of 0.7 for $e_{t}$ should cover both turbine losses and pumping.

Table 3. Expected power outputs.

\begin{tabular}{llcc}
\hline \multicolumn{1}{c}{ System } & $\begin{array}{c}\text { Ideal power } \\
\left(\mathrm{MW} / \mathrm{ft}^{2}\right)\end{array}$ & $\begin{array}{c}\text { Expected power } \\
(\mathrm{MW} / \mathrm{ft} 2)\end{array}$ & $\begin{array}{c}\text { System } \\
\text { efficiency } \\
(\%)\end{array}$ \\
\hline Flashed steam & $39.5 \mathrm{e}_{\mathrm{t}}$ & 27.7 & 11 \\
Binary fluid & $40.4 \mathrm{e}_{\mathrm{t}}$ & 28.3 & 11 \\
Total flow & $63.1 \mathrm{e}_{\mathrm{w}} \eta^{2}$ & 44.2 & 18 \\
\hline
\end{tabular}


COMPARISON OF SYSTEMS

We can now compare the three systems. Since the overall turbine efficiencies are all $\sim 70 \%$ it is evident that the total flow system is most efficient. Table 3 shows the expected power outputs $/ \mathrm{ft}^{2}$ of well. We define system efficiency in Table 3 as the ratio of the electric power generated to the recoverable energy from the wellhead product. Thus, we expect $60 \%$ more power from a given well from the total flow system than than from either alternate.
We can expect this increased power because the total flow system uses the entire mass flow rate and, hence, a higher conversion efficiency of thermal energy to kinetic energy. The flashed steam system uses only $29 \%$ of the mass as steam to drive the turbine while discarding the remaining as hot brine at $338^{\circ} \mathrm{F}$. The two-fluid system rejects all of the brine at $300^{\circ} \mathrm{F}$ at optimum efficiency. Reinjection of the hot brine is possible with all systems, so part of the rejected energy is returned to the reservoir.

\section{Turbine Systems}

\section{TURBINE CHOICE}

There is a wide variety of turbines, but they generally fall into two classes. The impulse turbine converts thermal energy to kinetic energy by a pressure drop through a nozzle only. The fluid kinetic energy is then converted to rotational energy by directing the stream to impinge on some kind of vane or bucket attached to a wheel. There is almost no pressure drop through the rotating components. The reaction turbine, usually used to recover energy from high pressure gases, operates by allowing the gas to expand as it passes through the rotating vanes, and this expansion is accompanied by a pressure drop. To prevent bypass of the rotating components there must be very close tolerances between the vanes and housings or stators.

Therefore, there are two possibilities for recovering energy from the full fluid stream: expanding the two-phase mixture through a nozzle to obtain high velocity jets that are used to drive an impulse turbine, with the entire pressure drop occurring in the nozzle, or expanding the two-phase mixture through a reaction turbine where both a velocity change and a pressure drop occur. The axial flow reaction turbine has a higher efficiency, normally operates at higher speeds, requires multiple stages, and is generally more complex, requiring very small clearances to maintain the pressure drop/ stage. But a multistage turbine cannot be expected to function reliably when driven directly by mixture of vapor, brine, silica, and, probably, sand and other extraneous materials.

This nature of the working fluid requires that the turbine be simple and easily maintained; the impulse turbine therefore appears to be the best choice. The most common impulse turbine is the axial flow configuration in which the fluid is fed through a series of nozzles located 
around the wheel periphery. The power output and efficiency of both single and multistage turbines is proportional to $\cos ^{2} \theta_{1}$ where $\theta_{1}$ is the nozzle angle. Experience in turbine design has shown $\theta_{1} \approx 20^{\circ}$; hence, maximum efficiencies are $\mathbf{8 8 \%}$. The influences of blade friction, leakage past the blade, turbulence, and fanning will reduce this efficiency. In addition, large axial forces can be developed, and control of vibration is always a serious factor in axial flow turbine design.

The other alternatives are radial and tangential flow impulse devices; these appear to be most promising for our application. They are shown schematically in Fig. 16. The radial flow device shown is similar to the Francis hydraulic turbine except that nozzles are used here in place of inlet guide vanes. Proper selection of the rotor inlet and outlet vane angles will direct the exit fluid radially inward with no tangential velocity component (whirl). In principle, the blade efficiency for this condition can be $100 \%$. This is unlikely, however, since turbulence losses will occur, and it may be necessary to select vane angles to give some whirl to the exit fluid. The advantages of the radial flow impulse turbine are high efficiency, reduced fanning losses, flexibility in choice of nozzle angle, reduced losses by jet dispersal, and minimal vibration problems. There are few vibration problems because the nozzle lies in the plane of the wheel, producing low axial forces.

The tangential flow turbine shown in Fig. $16 \mathrm{~b}$ is modeled after the Pelton wheel. Although it has only been used as a hydraulic turbine, there is no funda-

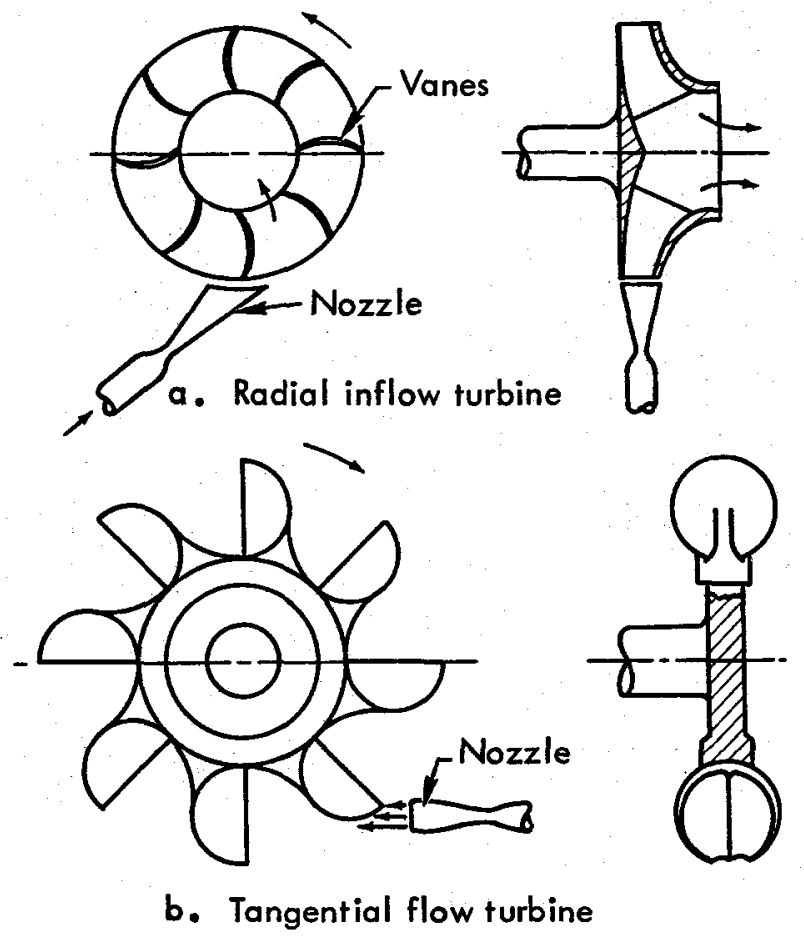

Fig. 16. Total flow impulse turbine concepts.

mental reason why it cannot be operated with a two-phase fluid. This device can have an efficiency as high as $95 \%$, depending on bucket splitter angle and exit angle. Blade friction, of course, may be important, but the major losses (and disadvantage) will probably result from fanning and jet dispersal, since the nozzles must be placed some distance away from the buckets. The major advantages, however, are inherent high efficiency, simplicity of fabrication (and resultant low cost), low potential for vibration, and the fact that the buckets may be readily replaced or relined. This latter point may be very important since the working fluid will be very corrosive.

Typically, hydraulically-operated devices of these types exhibit wheel efficiencies greater than $90 \%$. No data exist for operation in the two-phase flow 
regime, and it is not possible to report efficiencies for this operating condition. Nevertheless, there is no fundamental reason why gross differences should exist, so it seems reasonable that a twophase total flow turbine could be developed to give a $90 \%$ efficiency.

\section{TWO-PHASE FLOW THROUGH} NOZZLES

The efficiencies reported for the impulse turbines do not include the nozzle efficiency. If we define the nozzle velocity coefficient $\eta$ such that $v_{1}=\eta V_{\text {ideal }}$ ' then the overall turbine efficiency can be obtained by multiplying by $\eta^{2}$. Hence, nozzle efficiency is a critical factor. For gases and superheated steam $\eta>0.95$. For wet steam, however, the nozzle coefficient may be much lower because of the difference in velocities of water droplets and vapor. Much research ${ }^{17-19}$ has been done on the subject, but most of it has been restricted to investigations of the flow of high quality steam where the ratio of mass of vapor to total mass is $<20 \%$. Specifically, some data have been gathered $^{20-22}$ for low quality steam flowing through a converging diverging nozzle. The results shown in Fig. 17 indicate that mixtures containing $20 \%$ vapor can be expanded with nozzle coefficients of $\sim 0.9$. While these are the only such data available, the results are very encouraging, since authors of the work emphasized that no attempt was made to optimize the nozzle design. Hence, it appears possible to achieve high nozzle coefficients $(>0.9)$ by careful experimentation and testing to determine the optimum nozzle configuration.

Figure 18 shows the combined effect of nozzle coefficient and turbine efficiency and compares the ratio of the power outputs from the total flow system and the flashed steam system. The curve is constructed with the condition that the turbine efficiency, $e_{t}$, of the flashed steam system is $70 \%$. The results show

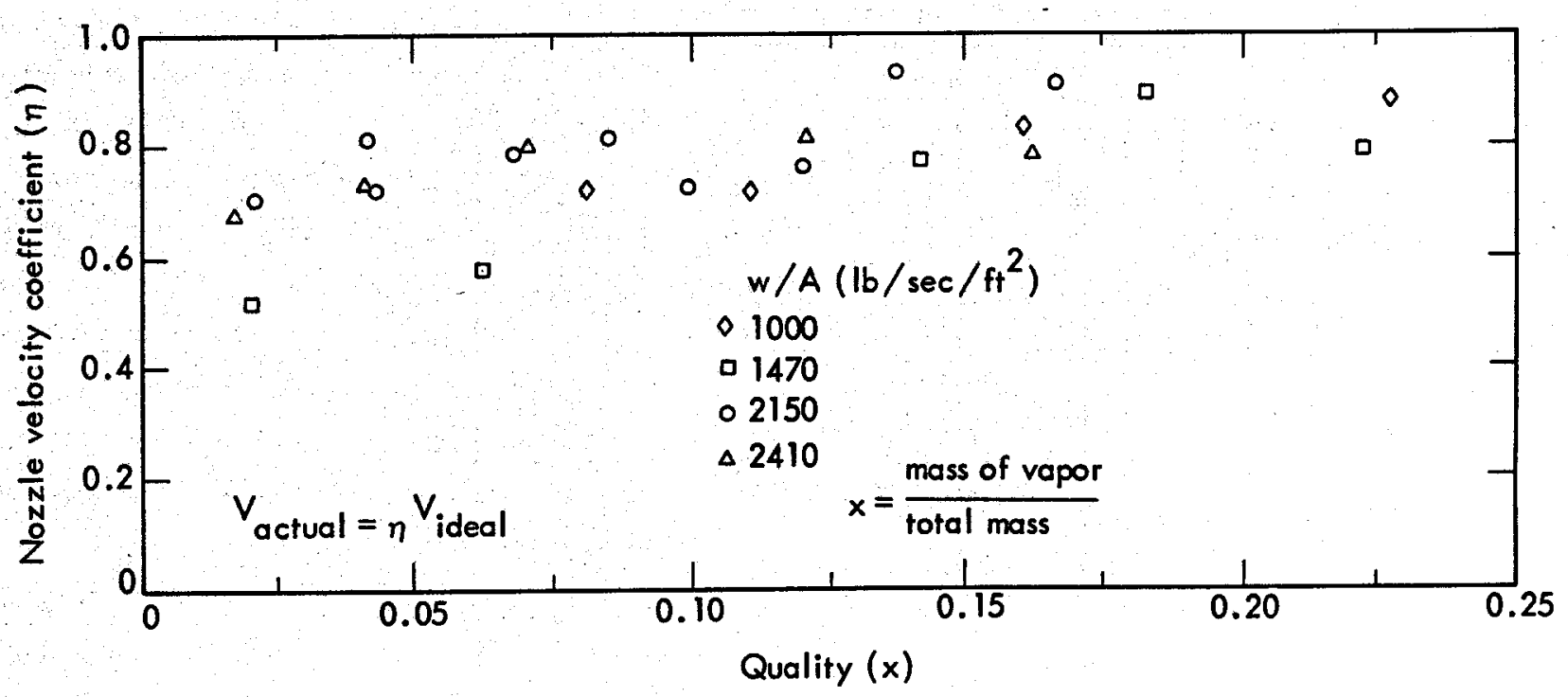

Fig. 17. Performance of two-phase flow through a converging-diverging nozzle. 


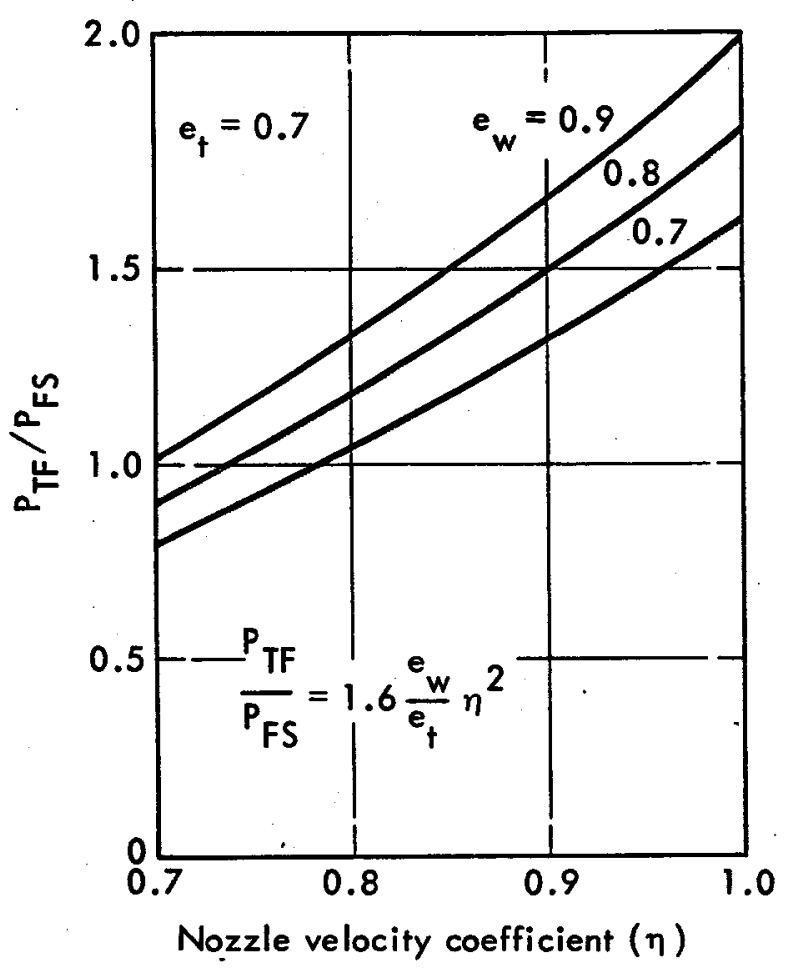

Fig. 18. Comparison of the actual power output of the two-phase system with the flashed steam system. that for $50 \%$ more power, for example, the nozzle coefficient can be as low as 0.84 with a wheel efficiency of $90 \%$ or must be as high as 0.95 if the wheel efficiency is as low as $70 \%$.

\section{A TRIAL CONCEPT}

To discuss the nature of the design problem, we shall examine one possible system. It should be recognized that this example is intended only for illustrative purposes, and is not necessarily the optimum. Figure 19 is an elevation view of an installation with a radial inflow turbine. We assume a nozzle coefficient of 0.9, with wellhead conditions taken from Table 2, as the input data for calculating nozzle exit conditions. For a condensing temperature of $120^{\circ} \mathrm{F}$ at 1.7 psia Table 4

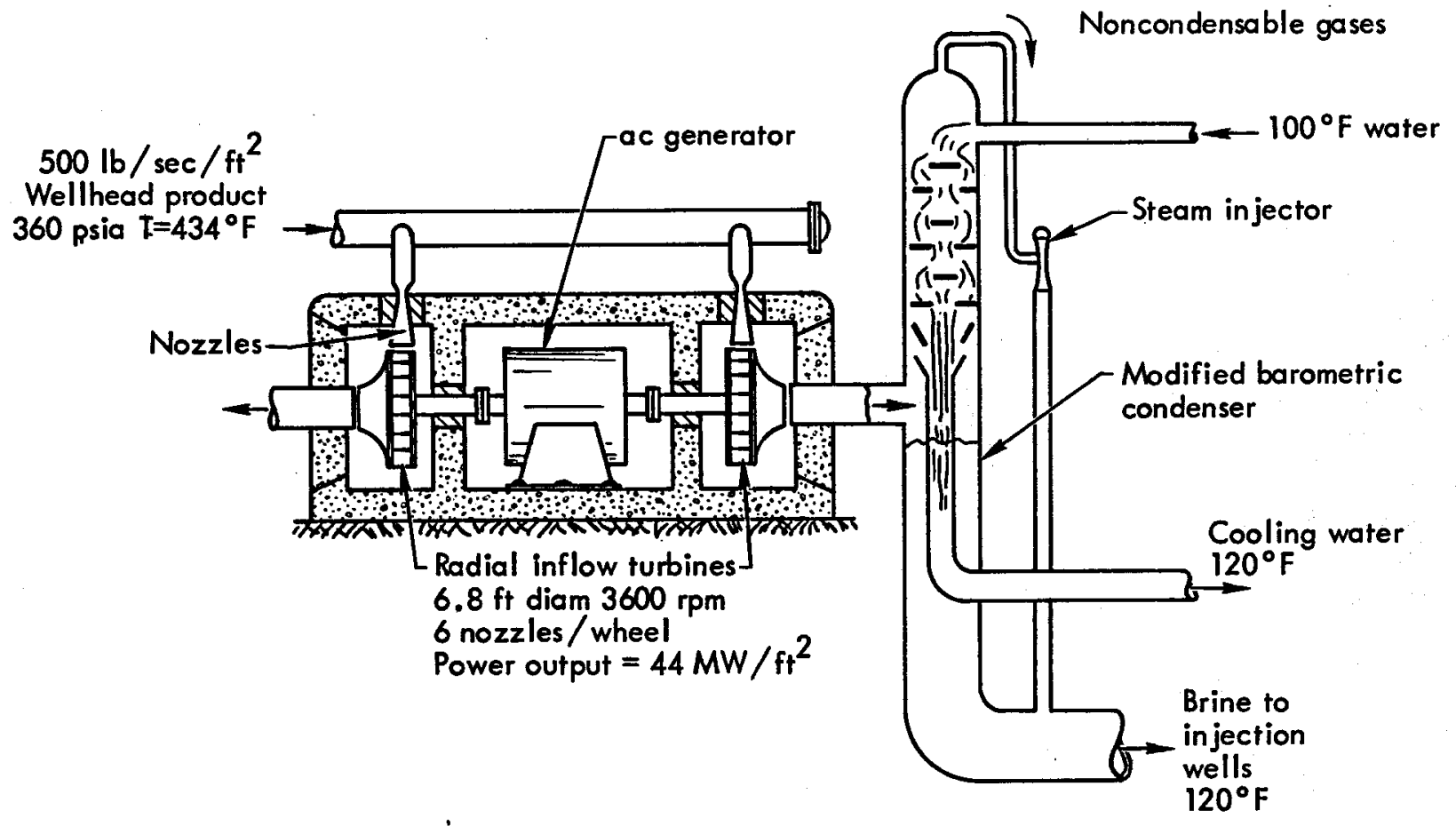

Fig. 19. Schematic of a total flow system. 
Table 4. Exit conditions from nozzle and turbine.

\begin{tabular}{lcccccc}
\hline & $\begin{array}{c}\mathrm{p} \\
(\mathrm{psia})\end{array}$ & $\begin{array}{c}\mathrm{x} \\
(\%)\end{array}$ & $\begin{array}{c}\mathrm{h} \\
(\mathrm{Btu} / \mathrm{lb})\end{array}$ & $\begin{array}{c}\mathrm{v} \\
\left(\mathrm{ft}^{3} / \mathrm{lb}\right)\end{array}$ & $\begin{array}{c}\mathrm{V} \\
(\mathrm{fps})\end{array}$ & $\begin{array}{c}\mathrm{A} \\
\left(\mathrm{ft}^{2}\right)\end{array}$ \\
\hline Wellhead & 360 & 0.19 & 562.5 & 0.26 & 130 & 1 \\
Nozzle outlet & 1.7 & 0.37 & 465.7 & 75.2 & 2205 & 17.1 \\
Turbine outlet & 1.7 & 0.37 & 465.7 & 75.2 & 965 & 17.1 \\
\hline
\end{tabular}

describes the exit condition from nozzle to turbine and from turbine to condenser.

Since the jet area is 17 times the inlet area, multiple nozzles and/or wheels will be necessary. The particular system chosen for this example is a single generator operated by two turbines with six nozzles/wheel. In this case the turbines have a diameter of $6.8 \mathrm{ft}$, rotate at $3600 \mathrm{rpm}$, contain nine equally spaced vanes, and (with an assumed turbine efficiency of $90 \%$ ) produce about $44 \mathrm{MW} / \mathrm{ft}^{2}$ of wellbore area. Hence, this power output requires two 9-5/8-in. i.d. wells, each flowing at $250 \mathrm{lb} / \mathrm{sec}$.

This is not a large system compared to conventional hydraulic installations; however, the peripheral wheel speed is much higher than usual and will result in high stress levels, somewhere between 50,000 and 70,000 psi for a steel wheel. The stresses would scale down linearly with density for lighter materials, but it may prove more effective to develop design alternatives that either use lower mass flow rates per turbine or smaller nozzle angles or reguire pressure staging as a means of lowering peripheral wheel velocity. A two-stage device, for example, reduces the peripheral velocity enough to reduce the stress to $40 \%$ of its former value, but it makes a more complex and possibly less efficient system. Nevertheless, many alternatives exist, and arriving at an optimized system will be a fundamental goal of a research and development program.

The barometric condenser can do the cooling (see Fig. 19), and could be modified as indicated to allow return of the cooling water without excessive contamination by the exhaust brine. The cooling water can be fed through either a cooling tower or a spray pond. Our preliminary calculations indicate that for a cooling range of $20^{\circ} \mathrm{F}$, each $44-\mathrm{MW}$ module (500-lb/sec flow) requires $29000 \mathrm{lb} / \mathrm{sec}$ of cooling water flowing between the condenser and pond. This includes $170 \mathrm{lb} /$ sec added from the condensed vapor. The evaporative cooling loss is calculated to be $172 \mathrm{lb} / \mathrm{sec}$. Depending on drift losses, there will be either a small net gain or loss in cooling water flow. Since there are usually no strong prevailing winds in the area, a circular spray pond with nozzles spaced equally along the periphery of circles with radii every $25 \mathrm{ft}$ would function effectively from vertical air movement by convection. We need detailed information on the composition of the condensed vapor phase, however, to select the optimum cooling system. Disposal of the concentrated brine outflow from the barometric condenser will be done by injection through a number of wells equal to the number of production wells and extending to about the same depth. 


\section{Chemical and Corrosion Factors}

The major problem with the brines in the Salton Sea-Mexicali Valley province results from their chemical composition (see Table 1). These brines are corrosive in the extreme, cause scale deposits, and under certain circumstances can saturate and deposit salts.

\section{BRINE PHYSICAL AND} THERMAL PROPERTIES

The specific weight of the brine varies with pressure and temperature, as shown in Fig. 20. We calculated this curve by assuming no flashing. The specific weight of the brine at the turbine outlet after $36.8 \%$ of the water is vaporized is $75.7 \mathrm{lb} / \mathrm{ft}^{3}$. The average specific weight of the brine in the reservoir is $\sim 62 \mathrm{lb} / \mathrm{ft}^{3}$. Therefore, the reservoir pressure is greatly exceeded by the hydrostatic pressure developed in the injection wells. For a 5100-ft well, the bottom hole pressure difference will be $\sim 556 \mathrm{lb} / \mathrm{in}^{2}$. If silica does not plug the injection well and injection pressures are the inverse of drawdown pressures, the injection wells will accept up to $700 \mathrm{lb} / \mathrm{sec} / \mathrm{ft}^{2}$ of well before injection pumps are needed. Since we estimate production to be $500 \mathrm{lb} / \mathrm{sec} /$ $\mathrm{ft}^{2}$ of well, it is probable that no significant energy will be needed for injection.

In the thermodynamics and turbine analyses we assumed that the properties of brine were approximately those of the same weight of pure water. Since $1 \mathrm{lb}$ of mixture at the wellhead contains only $-0.743 \mathrm{lb}$ of water and $0.257 \mathrm{lb}$ of salt, the heat available from water is only $70 \%$ as great as indicated in the Steam Tables 15 plus the heat available from cooling the

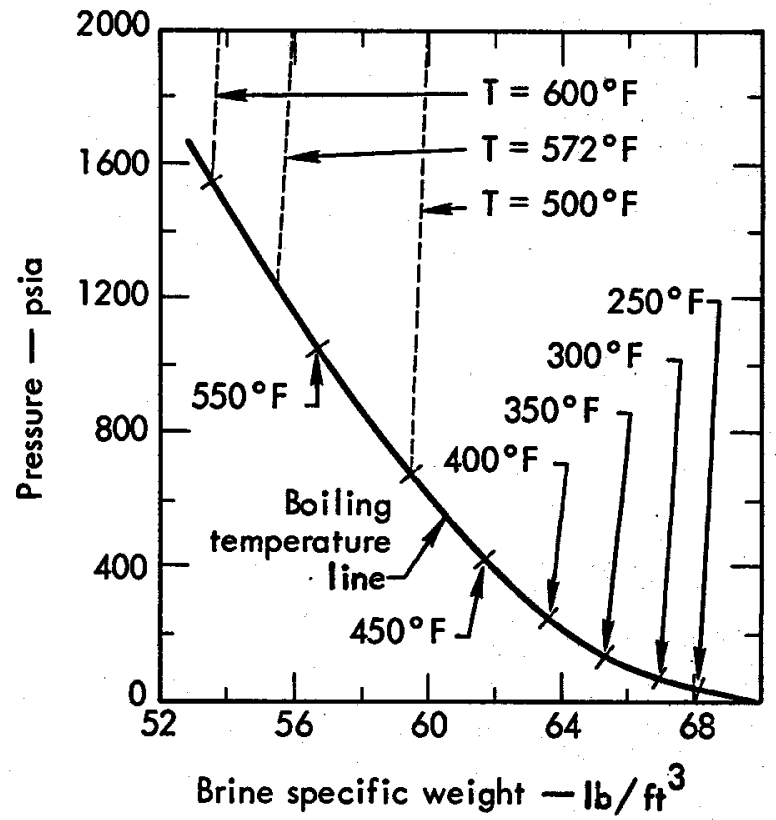

Fig. 20. Brine properties.

salt. The enthalpy available from water vaporization during passage through the nozzle, shown in Table 4 , is $98.8 \mathrm{Btu} / \mathrm{lb}$, or $71.9 \mathrm{Btu} / \mathrm{lb}$ of brine. The heat capacity of the salt is $\sim 0.2 \mathrm{Btu} / 1 \mathrm{~b}-{ }^{\circ} \mathrm{F}$ so dropping from $434^{\circ} \mathrm{F}$ to $120^{\circ} \mathrm{F}$ yields $16.1 \mathrm{Btu} /$ $\mathrm{lb}$ of brine. Thus, the net heat available to do work as the brine passes through the nozzle is $88.0 \mathrm{Btu} / \mathrm{lb}$, or $\sim 9 \%$ less than from pure water. In this sense, the power calculations in the thermodynamic analysis may be too high by approximately this amount; however, in view of all the estimated factors involved, we do not feel the expected power output shown in Table 3 is in serious error.

\section{CORROSION}

Geothermal brines are notorious for their corrosive character. Considerable 
work has been done evaluating both corrosion and stress-induced corrosion in the brines at Wairakei, New Zealand. ${ }^{23}$ The Wairakei brines were $\sim 10 \%$ as concentrated and somewhat cooler than those found near the Salton Sea, so the information must be used with caution. Foster et al. found that titanium resisted the brines reasonably well, 22 but the Wairakei brines are strongly basic (pH 8.4-8.6) while the Salton Sea brines are likely acid. Titanium is less reactive in neutral or alkaline solutions than in acid solutions and is particularly susceptible to crevice corrosion and hydrogen embrittlement in a highly acidic environment. We therefore feel that titanium may not be acceptable in the California brines. The $13 \%$ chrome ferritic stainless steels at Rockwell B-60 to C-28 hardness were also found to be satisfactory in New Zealand, and should be investigated for application in California. Monel metal, inconel and Hastalloy are known to be unsatisfactory. The only materials surely corrosion-resistant to the Salton Sea brine are ceramics, tantalum, plastics, and perhaps zirconium. Methods for tantalum plating have been developed, making tantalum-coated steel a possible production tubing, but costs will probably be high. The high temperature plastics, such as Teflon, used for cookingware coating may prove satisfactory. Glass lining or all glass may also be considered for use as well production tubing. The

\footnotetext{
Reference to a company or product name does not imply approval or recommendation of the product by the University of California or the U.S. Atomic Energy Commission to the exclusion of others that may be suitable.
}

nozzles and turbine components can probably be tantalum coated, but if extreme abrasion resistance is needed, tantalum carbide linings may be necessary. Even though much of the advanced materials technology exists, a development program will be required to apply this knowledge for commercial production of corrosion resistant components and to minimize scale formation.

\section{SCALE FORMATION}

Scale comprised of magnetite $\left(\mathrm{Fe}_{3} \mathrm{O}_{4}\right)$, Hausmanite $\left(\mathrm{Mn}_{3} \mathrm{O}_{4}\right)$ and silica $\left(\mathrm{SiO}_{2}\right)$ has been observed to form in wellhead plumbing at every well tested. This scale is reported to form on any surface; even such inert materials as Teflon are soon deeply coated.

In our opinion formation of such scales is a consequence of the material used for well casing. There is a series of reactions between iron ions and water of the form

$$
2 \mathrm{Fe}^{+3}+\mathrm{Fe}^{+2}+4 \mathrm{H}_{2} \mathrm{O} \rightleftharpoons \mathrm{Fe}_{3} \mathrm{O}_{4}+8 \mathrm{H}^{+}
$$

Similar reactions occur between manganese ions and water. These reactions are reversible as long as the solution remains in contact with the scale, and when the acid strength reaches $\sim \mathrm{pH} 3$, no further scale should be formed. In the formation we expect that no scale is being formed and the solution is stable. If, however, the solution contacts a material that consumes acid (e.g., limestone) or a reactive metal (e.g., iron), the equilibrium is disturbed by removal of acid and more scale and acid are formed while iron is removed from solution. Thus, we 
Table 5. Compound concentrations and solubility.

\begin{tabular}{llll}
\hline Compound & $\begin{array}{c}\text { Concentration } \\
\left(\mathrm{g} / \mathrm{cm}^{3}\right)\end{array}$ & $\begin{array}{c}\text { Solubility at } \\
100^{\circ} \mathrm{C}\left(\mathrm{g} / \mathrm{cm}^{3}\right)\end{array}$ & $\begin{array}{c}\text { Concentration/ } \\
\text { solubility }\end{array}$ \\
\hline $\mathrm{NaCl}$ & 0.1345 & 0.346 & 0.389 \\
$\mathrm{KCl}$ & 0.0315 & 0.502 & 0.063 \\
$\mathrm{CaCl}_{2}$ & 0.0772 & 1.41 & 0.055 \\
$\mathrm{LiCl}^{2}$ & 0.00128 & 1.13 & 0.0011 \\
$\mathrm{MgCl}_{2}$ & 0.000039 & 0.374 & 0.00010 \\
$\mathrm{SiCl}_{2}$ & 0.000796 & 0.089 & 0.0089 \\
$\mathrm{BaCl}_{2}$ & 0.000375 & 0.523 & 0.00072 \\
$\mathrm{RbCl}^{2}$ & 0.000099 & 1.231 & 0.00008 \\
$\mathrm{CsCl}^{2}$ & 0.0000253 & 2.40 & 0.000010 \\
$\mathrm{FeCl}_{3}$ & 0.00581 & 4.75 & 0.00122 \\
$\mathrm{MnCl}_{3}$ & 0.00402 & $1 \mathrm{arge}$ & small \\
$\mathrm{PbCl}^{2}$ & 0.000107 & 0.0296 & 0.0036 \\
$\mathrm{ZnCl}_{2}$ & 0.00104 & 5.45 & 0.00019 \\
$\mathrm{CnCl}_{2}$ & 0.0000169 & 0.957 & 0.000018 \\
$\mathrm{SiO}_{2}$ & 0.000400 & - & - \\
$\mathrm{H}_{2} \mathrm{O}$ & 0.8862 & $\infty$ & 0 \\
\hline
\end{tabular}

believe scale formation can be minimized by meticulous avoidance of any material that reacts with acid at $\mathrm{pH} 3$ in the well or surface equipment. For example, ordinary cement will probably react with the solution and cause scale formation until sufficient scale is deposited to seal the cement from contact with the solutions. Cements used in well completion must be compatible with high acid concentrations (e.g., gypsum-based cements).

\section{BRINE SATURATION}

Using Helgeson's analysis ${ }^{8}$ (Table 1, Column 2), we recalculated the brine composition as the sum of a group of chemical compounds. Table 5 shows these compound concentrations and their solubility at $100^{\circ} \mathrm{C}$. In general, their solubility increases with temperature.
As the right column shows, $\mathrm{NaCl}$ is closest to saturation, and as steam flashes from the brine, it will begin to precipitate when $61.1 \%$ of the water is vaporized. This concentration is never reached in the total flow system. The calculated steam quality at the points of highest concentration (nozzle outlet, turbine chamber, and barometric condenser) is $36.8 \%$, which is the same as removing $0.326 \mathrm{lb}$ of water/lb of original brine, or $\sim 70 \%$ of saturation. At $25^{\circ} \mathrm{C}$ the solubility of $\mathrm{NaCl}$ is $0.316 \mathrm{~g} / \mathrm{cm}^{3}$, so if the brine were cooled separate from the vapor, salt would reach saturation when $57.4 \%$ of the water was removed. Concentrations never approach these values in the total flow system, so we expect no problems from salt formation.

The $\mathrm{SiO}_{2}$ solubility is not shown in Table 5 because its solubility is a 
complex function of both temperature and pressure. In all likelihood, the $\mathrm{SiO}_{2}$ concentration is in saturated equilibrium in the formations, and this should be very close to the saturated equilibrium value for quartz-water or amorphous silicawater corrected for the presence of other salts. Figure 21 shows the lower twophase region of the quartz-water system corrected for the presence of other salts on the assumption that there are no chemical reactions between the other salts and silica. If the actual solubility is more like amorphous silica in hot water, then the silica will be 2.5 times more abundant at the higher temperatures. Below $\sim 450^{\circ} \mathrm{F}$ the actual value will be close to that shown. Therefore, as the brine passes up the well and through the nozzle, silica will be continuously precipitated. Assuming $300^{\circ} \mathrm{C}$ initial reservoir temperatures, the brine will carry more than $600 \mathrm{ppm}$ of $\mathrm{SiO}_{2}$. At the nozzle outlet $\left(120^{\circ} \mathrm{F}\right)$ essentially all this will be insoluble, so silica will be produced in the condenser outlet at the rate of $25,920 \mathrm{lb} /$ day $/ \mathrm{ft}^{2}$ of well if the brine flow rate is $500 \mathrm{lb} / \mathrm{sec} / \mathrm{ft}^{2}$ of well. This amorphous silica will create a serious problem if it does not remain in colloidal suspension from production through injection. If the brine acidity is not disturbed, the silica should be expected to remain colloidal.

\section{WELL COMPLETION DESIGN}

We discussed certain aspects of the wells in connection with the thermodynamics analysis; however, possible downhole salt precipitation may impose additional constraints. Several problems

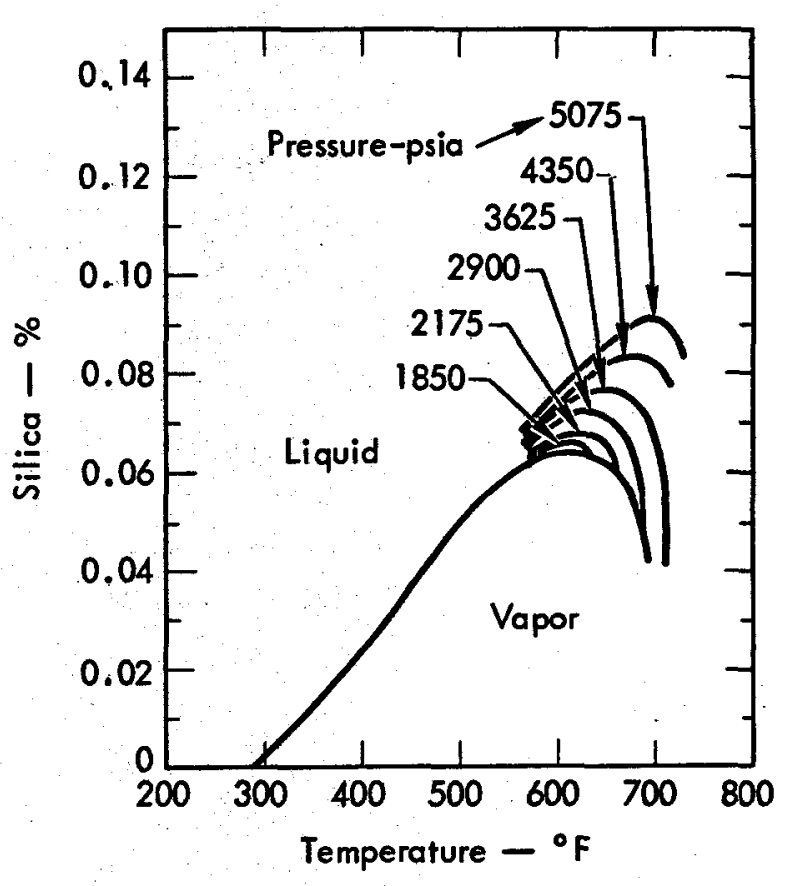

Fig. 21. Lower three-phase region of the silica-water system, corrected for salt.

have been encountered during well completions. First, during casing at intermediate levels, the annular space between casings must not contain confined water. If water is left in the annulus during cementing, it heats up during steam production and collapses the inner casing or production tubing when it expands. Second, flow velocities from the point of vapor formation to the wellhead must be high enough that appreciable "slip" of brine does not occur. At low flow velocities there is a tendency for the vapor phase, as bubbles, to rise faster than the liquid. This causes higher and higher salt concentrations in the well and the concentration at which salt could precipitate might conceivably be reached. The two-phase mixture can be produced without salt concentrating if the flow velocities are maintained above $100 \mathrm{fps}$. Figure 20 shows that the specific weight 
of the brine in the deep well averages $56 \mathrm{lb} / \mathrm{ft}^{3}$. Thus, $500 \mathrm{lb} / \mathrm{sec}$ is equivalent to $8.9 \mathrm{ft}^{3} / \mathrm{sec}$; since this mass flow is associated with $1 \mathrm{ft}^{2}$ of well, the brine velocity in the lower pipe is 8.9 fps. To achieve $100 \mathrm{fps}$ the diameter should be reduced to 0.30 times its original value. A 9-5/8-in. casing would be reduced to 2.89 in. at that depth, for example. As the brine-vapor mixture passes up the pipe and more vapor is formed, the diameter should be increased again to keep the flow velocity from becoming too high and increasing the pressure drop due to frictional losses.

Assuming $200 \mathrm{fps}$ as an upper limit to velocity, the production casing area can be determined directly from the continuity equation. Since $\mathrm{v}$ is $\sim 0.25$ $\mathrm{ft}^{3} / \mathrm{lb}$ at the wellhead, the area is -0.625 $\mathrm{ft}^{2}$, or, for a 9-5/8-in. well, the tubing diameter at the surface would be 7.6 in. Figure 22 is a schematic drawing showing the entire well casing and production tubing in concept. As shown in Fig. 22, 30 -in. surface conductor would be set in a 36-in. hole to a depth of $200 \mathrm{ft}$. The hole would then be drilled at 24-in. diam to $2300 \mathrm{ft}$ and an 18 -in. diam casing set at that depth. Then the hole would be drilled at 17-1/2-in. diam to $4350 \mathrm{ft}$ and a 13-5/8-in. casing set and carefully cemented. The hole would be completed to $5000 \mathrm{ft}$ with a 12-in. bit. The production tubing string would consist of corrosion-resistant material with wipers set at $\sim 4000 \mathrm{ft}$ on a section $9-5 / 8-i n$. diam tubing that would extend from 5000

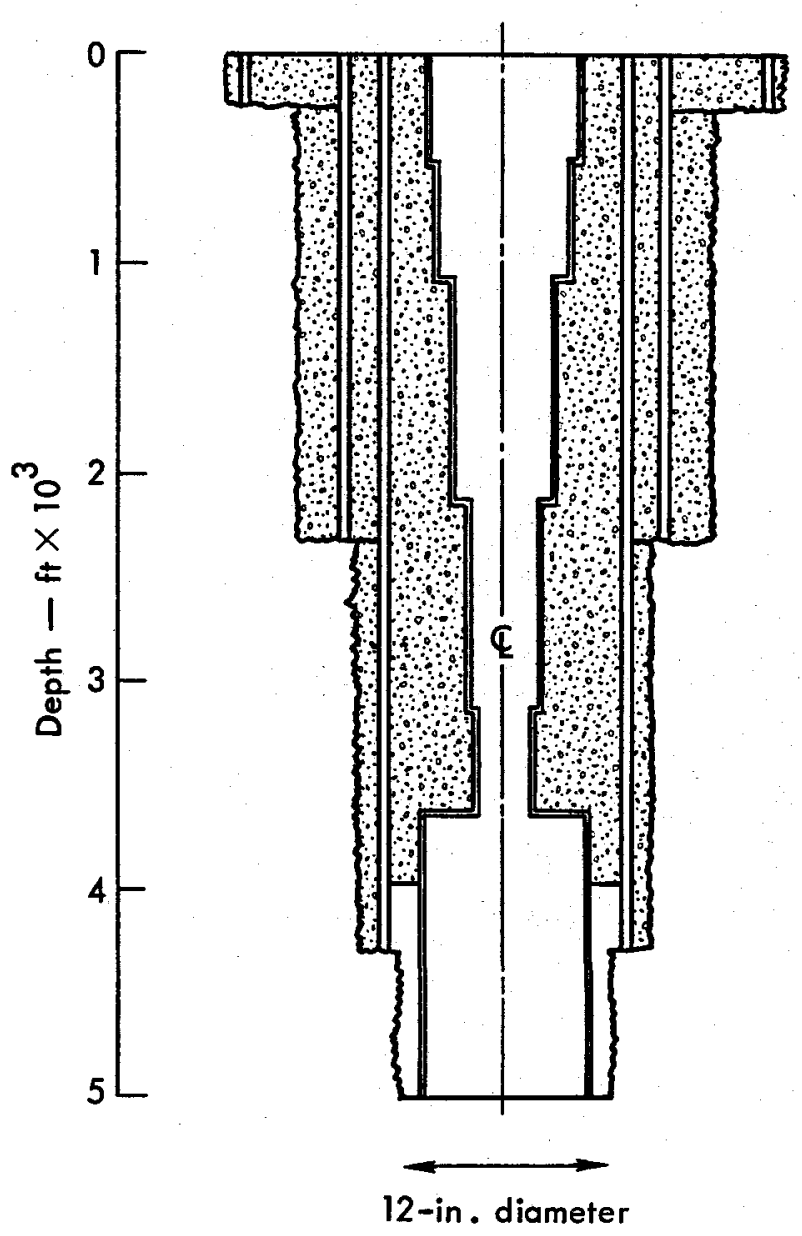

Fig. 22. Well casing diagram.

to $3650 \mathrm{ft}$ and be perforated or slotted below $4600 \mathrm{ft}$. From $3650 \mathrm{ft}$ to the surface there would be $500 \mathrm{ft}$ of 3-in. tubing, then $1000 \mathrm{ft}$ of 4 -in tubing, $1200 \mathrm{ft}$ of 5-5/8-in. tubing, $500 \mathrm{ft}$ of 7-5/8-in. tubing, and $450 \mathrm{ft}$ of 8-5/8-in. tubing. With such a production tubing, flow velocities will be between 100 and 200 fps everywhere. It is not yet clear whether the whole annulus between the production tubing and casing should be cemented or left partly open to facilitate replacement. 


\section{Environmental Considerations}

The total flow geothermal power system will have little adverse environmental impact. Since fluids are to be produced and injected at the same depth there will be no subsidence or accumulation of salts or brine on the surface or in any other aquifer. Noncondensable gases are to be injected by aspirator into the disposal wells so there will be no atmospheric contamination. It is necessary to have an inventory of less concentrated brine circulating between the barometric condenser and cooling system. It is expected that this might amount to $\sim 5,000,000 \mathrm{ft}^{3}$ circulating at a rate of $\sim 45,000 \mathrm{lb} / \mathrm{sec}$ for a 220-MW power module. This brine could be contained in an impermeable earthern pond of about a $400-\mathrm{ft}$ radius by
$6 \mathrm{ft}$ deep. Unless this tank were breached, there should be no adverse contact between the brine and the environment or ground waters. The turbines will be noisy if unshielded, but since they possess so much stored energy it will be necessary to build massive protective cases anyway. It may be desirable to emplace the entire power station except the cooling water system and transformer bank just below ground level to provide earthen sound barriers and shields.

In all, a fully developed geothermal brine area would have transformer banks, cooling ponds, wells, and generators occupying only $\sim 5 \%$ of the surface of the land. Such a development should be able to produce all the underlying geothermal energy.

\section{Cost Estimates}

Estimating costs of an operating geothermal total flow system is difficult, since neither the materials nor machine design problems are solved and the optimum cooling system is unknown. Nevertheless, it is desirable to make a crude economic evaluation to determine if geothermal power development should be undertaken.

In this analysis we have tried to arrive at an estimate that is valid to within $30 \%$ by scaling costs of analagous plant equipment from the chemical industry, from other g e othermal plants, and from the petroleum industry. Hopefully the estimate is as likely to be too high as too low.

\section{ASS UMPTIONS}

We assume the plant module to be served by 10 producing wells of $9-5 / 8-$ in . nominal production diameter driving three to five alternators, each with two turbines. In case the radial flow machine is used, each turbine would be driven from one well and two turbines could be used to drive one alternator, so there would be five turbine alternator combinations in the module. With the tangential flow turbine, each wheel would be driven by one well, with four wheels for each alternator. Peak capacity of the module is $220 \mathrm{MW}$ and with a load factor of $80 \%$, the annual power production if 1.53 billion 
kWh. We assume that each such module will be constructed independent of all others, so there will be no shared shops, utilities, transformer substations, or management. Finally, all estimates are based on the assumption that research and development has been completed and experience has been gained from a commercial scale pilot plant. The first plant will probably be the most expensive.

\section{CAPITAL COSTS}

The major elements of capital requirement are the production and reinjection wells, power house and plant that houses and services the wells and turbo-generators, the turbinealternators, and a high voltage substation.

In estimating the production and reinjection well costs, we assumed them to be the same as offshore wells drilled to the same depth. In addition, the cost of an exotic production tubing was added as if it were fabricated of pure titanium, although it very well may not be titanium and may be more or less costly. A hole loss factor of 0.2 has been assumed; that is, we assume that during drilling one of each five attempts to complete a hole will be unsuccessful. These lost holes were distributed against the drilling costs of the completed wells at a value equal to $75 \%$ of the base drilling cost without the completion tubing. The well life is assumed to be $20 \mathrm{yr}$. The estimates are

Drilling and casing 20 wells, $5000 \mathrm{ft}$ ea @ \$20/ft

$\$ 2,000,000$

Lost hole allowance, $20,000 \mathrm{ft} @ \$ 15 / \mathrm{ft}$ 300,000

Special tubing, $100,000 \mathrm{ft}$ @ $\$ 22 / \mathrm{ft}$

Contingency@15\%

Subtotal
We estimated capital investment for the remainder of the facility from New Zealand experience, appropriately inflated to $1973 .^{24}$ Note that all these costs are higher than current fossil fired plants; we used them for conservatism.

Power house and plant facility @ $\$ 49.50 / \mathrm{kW} \quad \$ 10,791,000$

Turbine and generator (Q) $\$ 56.54 / \mathrm{kW}$

Cooling system @ $\$ 17.62 / \mathrm{kW}$ $3,841,160$

High voltage substation (a) $\$ 11.11 / \mathrm{kW}$ $2,421,980$

Contingency@15\% $4,406,979$

Subtotal $\$ 33,786,839$

The drilling costs totaling $\$ 51.75 / \mathrm{ft}$ compare favorably with the costs in New Zealand, which are $\$ 51.10 / \mathrm{ft}$ when inflated to 1972-73 dollars. ${ }^{25}$ Table 6 shows the total capital costs. Note that the greatest uncertainty is the tubing cost. However, even if the cost were multiplied fivefold, the capital costs increase to only $\$ 214 / \mathrm{kW}$, which is still less than current systems. All capital construction costs include architect and engineer fees, land, utilities, and services.

\section{OPERATING COSTS}

We estimated operating costs by using operating chemical process plant 26 figures augmented by an assumed well maintenance cost. We assumed well production life to be $20 \mathrm{yr}$, but we assumed that the production tubing would be replaced every $5 \mathrm{yr}$. To average this cost we allocated an annual operating cost equal to $20 \%$ of the initial capital cost of production tubing. We estimated maintenance and plant repair at $1 \% / \mathrm{yr}$ of 
Table 6. Capital cost summary.

Drilling

Power house, plant, and high voltage substation

Turbines, generators, and cooling system

Total capital

Capital costs $/ \mathrm{kW}$
$\$ 5,175,000$

$\$ 15,194,927$

$18,591,912$

$\$ 38,961,839$ (or $\$ 40,000,000$ )

$\$ 180$

Table 7. Annual operating cost summary.

Production well maintenance

Power house, plant, and substation maintenance

Turbines, generators, and cooling system maintenance

Labor and supervision

State and local taxes

Insurance

Contingency@30\%

Total cost of sales
$\$ 506,000$

151,949

929,596

190,362

243,511

389,618

723,310

$\$ 3,134,346$ (or $\$ 3,000,000$ ) original capital cost of the power house, plant, and high voltage substation and $5 \% / \mathrm{yr}$ for the units subject to corrosion: turbines, generators, and cooling system. To calculate operating labor and supervision, we assumed that two operators would be required on each shift and that there would also be two craftsmen required on each weekday shift. We added a $30 \%$ supervision cost. State and local taxes were calculated as $5 \%$ of the assessed valuation, which was estimated as $25 \%$ of the depreciated capital value of the whole facility. This is shown in the cost summary for the average year at $0.625 \%$ of the initial capital cost. Insurance is shown as $1 \%$ of the initial capital cost and a contingency of $30 \%$ is included because of the gross method used in calculating maintenance and operating expenses. Corporate management is in- cluded in the maintenance costs. Table 7 summarizes the operating costs.

\section{CASH FLOW AND}

PROFITABILITY

There are a number of uncertainties that prevent a rigorous cash flow analysis. These include lease royalty rate, depletion allowance, regulated permissible rate of return, method of financing, and corporate tax structure for calculating federal income tax. In the example analysis below we have assumed an $80 \%$ load factor; without prejudice to future legal or regulatory actions, lease royalty at $12.5 \%$ and $5 \%$ of gross sales; internal financing; and computed internal rate of return as a function of power sales price.

Table 8 shows the example using 6 mills/kWh, $12 \%$ royalty, no depletion allowance, and $48 \%$ federal income tax. 
Table 8. Cash flow.

\begin{tabular}{|c|c|}
\hline Powersales@ @ $\$ 0.006 / \mathrm{kWh}$ & $\$ 9,180,000$ \\
\hline Royalty@12.5\% & $1,147,500$ \\
\hline Cost of sales & $3,134,347$ \\
\hline Gross profit & $\$ 4,898,153$ \\
\hline Depreciation & $\$ 1,948,092$ \\
\hline $\begin{array}{l}\text { Net profit before federal } \\
\text { income tax }\end{array}$ & $2,950,061$ \\
\hline Federal income tax & $1,416,029$ \\
\hline Net profit after taxes & $1,534,032$ \\
\hline Total cash flow & $3,482,124$ \\
\hline Years to return investment & 11.9 \\
\hline Internal rate of return & $6.4 \%$ \\
\hline
\end{tabular}

Figure 23 shows the rate of return on the investment for various power sales prices. The upper curve is calculated with $5 \%$ royalty and no federal income tax. The lower curve is calculated with $12-1 / 2 \%$ royalty, no depletion allowance, and $48 \%$ federal income tax. The actual profitability should fall between these two curves. Depreciation has been calculated as straight line for $20 \mathrm{yr}$ and the investment and plant life are assumed to be $.0 \mathrm{yr}$, with no recoverable value at the nd of the 20th year.

As Fig. 23 shows, there is no return on investor capital at a power sales price of $3.2 \mathrm{mills} / \mathrm{kWh}$, and, if bank rate interest is assumed to be $7.5 \%$, this investment yields in excess of bank rates for all power prices greater than 6.5 mills/ $\mathrm{kWh}$. The profit rate is not terribly sensitive to the royalty rate. For example, assuming a $5 \%$ royalty instead of $12.5 \%$ increases the rate of return at $8 \mathrm{mills} /$ $\mathrm{kWh}$ sales price from $11 \%$ to $12.5 \%$. At the same power sales price, eliminating

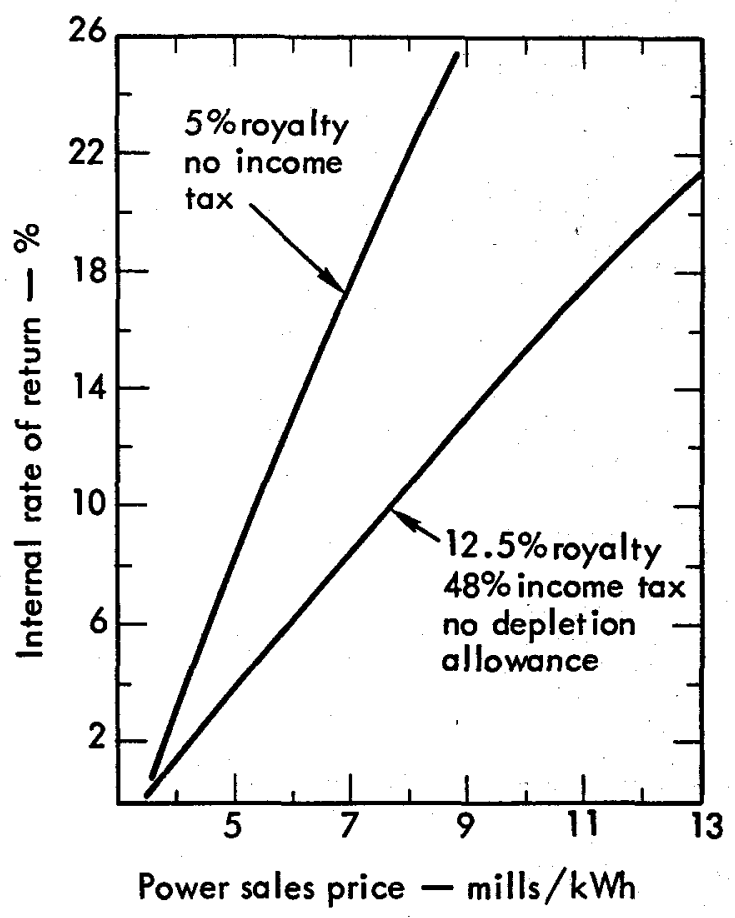

Fig. 23. Estimated range of effect of power sales price on internal rate of return.

federal income tax increases the internal rate of return from $11 \%$ to $19.1 \%$. If a $22 \%$ depletion allowance were permitted at $8 \mathrm{mills} / \mathrm{kWh}$ sales price, the internal rate of return would increase from $11 \%$ to $14.5 \%$.

In view of these calculations and considering that straight line depreciation and generous contingencies were used, we feel that development of the total flow geothermal power system should return profits to the investor commensurate with the risk at a rate competitive with fossil fuel or nuclear power generating systems. The state and local taxes should approach $\$ 100 \mathrm{million} / \mathrm{yr}$ if the whole resource is developed, and federal taxes would be 10 times as large. This represents a significant revenue to the whole public. 


\section{Conclusions}

The geothermal brine in the Salton Sea area of California represents a significant power source adjacent to high consumption areas. The method for converting these brines to electrical power using the whole fluid stream appears to be technically reasonable and economically attractive. An experimental program is needed to select materials that will withstand the corrosive brines, to find the best form of production tubing and well operation, to find the best turbine, and to demonstrate commercial feasibility of a power plant. None of these problems seem particularly formidable although few if any of the conventional methods and materials appear to be workable. We expect that the Salton Trough hot brines can be developed at a capital cost $<\$ 200 / \mathrm{kW}$ and for a power sales price $<8 \mathrm{mills} / \mathrm{kWh}$. Additional power sources may be developed at other areas having hot brines.

\section{Acknowledgments}

The creation of the concepts presented here is partly the result of the technical synergism we enjoy at LLL. Hence, the authors consider themselves not so much the originators, but more as a manifestation of the collective involvement of many people with a variety of technical backgrounds and interests. We are indebted to W. J. Ramsey for his stimulation of the original concept and to G. C. Werth, B. Rubin, S. D. Winter, and L. F. Wouters for their valuable criticisms and suggestions. 


\section{References}

1. D. E. White, Geothermal Energy, U.S. Geological Survey, Washington, D. C., Circular 519 (1965).

2. L. J.P. Muffler, U.S. Geological Survey, private communication (December 1972).

3. W. J. Hickel, Geothermal Energy, A National Proposal for Geothermal Resources Research, Final Report of the Geothermal Resources Research Conference, Seattle, 1972 (Battelle Research Center, Seattle, 1972), p. 15.

4. K. A. Seuse, AIAA J. $\underline{5}$ (11), 2097 (1967).

5. R. J. Rosa, Phys. Fluids 4 (2), 182 (1961).

6. J.B. Koenig, "Geothermal Exploration in the Western United States," preprint, U. N. Geothermal Symposium, Pisa, 1970.

7. L. T. Grose, Colo. Sch. Mines, Miner. Ind. Bull. 14 (6), 10 (1971).

8. H. C. Helgeson, Amer. J. Sci. 226, 129 (1968).

9. A. M. Mercado and A. Manon, "Mexicali Geothermal Field, General Characteristics," in Compendium of Papers, Imperial Valley-Salton Sea Area Geothermal Hearing, Sacramento, 1972 (State of California, Sacramento, 1972), paper Y.

10. L.C. Dutcher, W. F. Hardt, and W. R. Moyle, Jr., Preliminary Appraisal of Ground Water in Storage with Reference to Geothermal Resources in the Imperial Valley Area, California, U.S. Geological Survey, Washington, D. C., Circular 649 (1972).

11. L. C. Dutcher, U.S. Geological Survey, private communication (December 1972).

12. W. A. Elders, R.W. Rex, T. Meidar, P. T. Robinson, and S. Biehler, Science 178 (4056), 20 (1972).

13. C. Otte, "Drilling, Production and Disposal Technology in Salton Sea Geothermal Area, Imperial County, California," in Compendium of Papers, Imperial ValleySalton Sea Area Geothermal Hearing, Sacramento, 1972 (State of California, Sacramento, 1972), paper $R$.

14. B. Isacks, J. Oliver, and L. R. Sykes, J. Geophys. Res. 73, 5855 (1968).

15. J. H. Keenan and F.G. Keyes, Thermodynamic Properties of Steam (John Wiley and Sons, Inc., New York, 1955).

16. R. F. Carter, Imperial Valley Irrigation District, private communication (March 1973).

17. G. A. Goodenough, Power 66, 466 (1927).

18. J. I. Yellot and C. K. Holland, ASME Trans. 59, 171 (1937).

19. E. F. Church, Steam Turbines (McGraw-Hill Book Co., New York, 1950), Chap. 3 and 4.

20. R. E. Henry and H. K. Fauske, J. Heat Transfer, 179 (May 1971).

21. K. F. Neusen, Optimizing of Flow Parameters for the Expansion of Very Low Quality Steam, Lawrence Livermore Laboratory, Rept. UCRL-6152 (1962).

22. D. J. Maneely, A Study of the Expansion Process of Low Quality Steam Through a DeLaval Nozzle, Lawrence Livermore Laboratory, Rept. UCRL-6230 (1962). 
23. P. K. Foster, T. Marshall, and A. Tombs, "Corrosion Investigation of Hydrothermal Media at Wairakei, New Zealand," in Proc. Conf. on New Sources of Energy, Rome, 1961 (United Nations, New York, 1964), vol. 3, p. 186.

24. H.C. H. Armstad, "Geothermal Power Development at Wairakei, New Zealand," in Proc. Conf. on New Sources of Energy, Rome, 1961 (United Nations, New York, 1964), vol. 3, p. 274.

25. J. H. Smith, "The Organization for and Cost of Drilling Geothermal Steam Bores," in Proc. Conf. on New Sources of Energy, Rome, 1961 (United Nations, New York, 1964), vol. 3, p. 265.

26. M. S. Peters and K. D. Timmerhaus, Plant Design and Economics for Chemical Engineers (McGraw-Hill Book Co., New York, 1968), 2nd ed. 


\section{Distribution}

\section{LLL Internal Distribution}

Roger E. Batzel

W. Arnold

A. L. Austin

J. E. Carothers

A. F. Clark

T. K. Fowler

F. Fulton

W. Harford

A. C. Haussmann

G. H. Higgins

A. Holzer

J. H. Howard

A. Hudgins

W. E. Humphrey

J. S. Kahn

J.S. Kane

V. N. Karpenko

R. N. Keeler

A. Lewis

G. T. Longerbeam

A. W. Lundberg

A. Maimoni

R. C. Maninger

M. M. May

W. M. McClelland

E. R. McClure

C. A. McDonald

H. McDonald

R. L. Morton

P. H. Moulthrop

W. E. Nelson

M. Nordyke

T. Perlman

W. J. Ramsey

H. L. Reynolds

L. Roberts

B. Rubin

D. C. Sewell

J. Shearer
D. Stephens

R. G. Stone

E. Teller

J. Toman

R. Wagner

G. C. Werth

S. D. Winter

L. F. Wouters

TID File

External Distribution

Bethesda Technical Library

U.S. Atomic Energy Commission

Washington, D.C.

Division of Applied Technology

U. S. A tomic Energy Commission

Washington, D.C.

AEC Library

U. A. Atomic Energy Commission Washington, D. C.

ATTN: R.A. Anderson U.S. Atomic Energy Commission Washington, D. C.

U. S. Atomic Energy Commission San Francisco Operations Office Berkeley, California

Albuquerque Operations Office U.S. Atomic Energy Commission Albuquerque, New Mexico

Nevada Operations Office U.S. Atomic Energy Commission Las Vegas, Nevada

New York Operations Office U.S. Atomic Energy Commission New York, New York

Savannah River Operations Office U.S. Atomic Energy Commission Aiken, South Carolina

U.S. Mission to the Int'I Atomic Energy Agency

c/o U.S. Embassy

14 Schmidgasse

Vienna VIII, Austria 
External Distribution (continued)

ATTN: Library

Oak Ridge National Laboratory

Oak Ridge, Tennessee

L. Machta, Director

Air Resources Laboratory

Silver Springs, Maryland

ATTN: Library

U.S. Geological Survey

Denver, Colorado

ATTN: Library

U.S. Geological Survey

Flagstaff, Arizona

ATTN: P. Muffler

U. S. Geological Survey

Menlo Park, California

ATTN: W. T. Pecora

U.S. Geological Survey

Washington, D. C.

ATTN: J. Bridges

Congress of the U.S.

Washington, D. C.

Library of Congress

Exchange and Gift Division

Washington, D. C.

ATTN: H. Perry

Library of Congress

Washington, D.C.

ATTN: Reports Librarian Los Alamos Scientific Laboratory

Los Alamos, New Mexico

ATTN: L. B. Russel

National Aeronautics and Space Administration

Kennedy Space Center, Florida

Library Services Dept.

Argonne National Laboratory

Argonne, Illinois

ATTN: Research Library Brookhaven National Laboratory Upton, L.I., New York
ATTN: E. Abshire U.S. Bureau of Mines Albany, Oregon

ATTN: Librarian U.S. Bureau of Mines Denver, Colorado

ATTN: G. U. Dinneen U.S. Bureau of Mines Laramie, Wyoming

National Agricultural Library Department of Agriculture Beltsville, Maryland

ATTN: J. D. DeForest

Dept. of Commerce

Alexandria, Virginia

ATTN: A,C. Mailliaris

Dept. of Transportation

Cambridge, Massachusetts

S. M. Greenfield

Environmental Protection Agency

Washington, D. C.

M. W. Carter, Director

Environmental Protection Agency

Las Vegas, Nevada

ATTN: Acquisitions and Input Branch

NASA Scientific and Technical

Information Facility

College Park, Maryland

ATTN: Library

National Bureau of Standards

Washington, D. C.

Asst. Director for Research Applications

National Science Foundation

Washington, D. C.

Clearinghouse for Federal Scientific and Technical Information

TID-4500 Distribution, UC-51 Geology and Mineralogy

$\mathrm{JMB} / \mathrm{rt} / \mathrm{Ig}$ 